\title{
Validating a consumer-based service brand equity (CBSBE) model in the airline industry
}

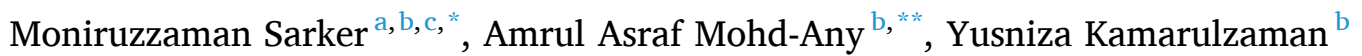 \\ ${ }^{a}$ Department of Marketing, Sunway University Business School, Sunway University, 47500, Bandar Sunway, Subang Jaya, Malaysia \\ ${ }^{\mathrm{b}}$ Department of Marketing, Faculty of Business and Accountancy, University of Malaya, 50603, Kuala Lumpur, Malaysia \\ c School of Business \& Economics, United International University, Dhaka, Bangladesh
}

\section{A R T I C L E I N F O}

\section{Keywords:}

Service branding

Service brand equity

Service experience

Airline service

PLS-SEM

Structural model robustness

\begin{abstract}
A B S T R A C T
Over time, scholars have argued that consumer-based brand equity (CBBE) models are less suitable for servicedominant brands, mainly because the role of customer experience with services is often disregarded. Also, the absence of two essential components, brand consistency and perceived value, signals a lack of depth in creating service brand equity. To address these gaps, we examine service-branding theory by conceptualizing and validating a consumer-based service brand equity (CBSBE) model in Sarker et al. (2019) in the context of airlines. Airline service direct experience and brand consistency are highly important aspects for strengthening brand equity components of services. Subsequently, maximizing perceived value, followed by creating favorable brand meaning are the nucleus of branding services. Using the most advanced PLS-SEM techniques, our CBSBE model is highly robust in explaining the theoretical notion of creating service brand equity. Thus, achieving a pleasant and desirable experience and maintaining consistency across direct service touchpoints would be an effective strategy for service organizations.
\end{abstract}

\section{Introduction}

Brand equity creation has long been an important subject in brand management. Brand equity refers to the differential consumer response (Keller, 1993), assets or liabilities (Aaker, 1991) associated with a brand and a source of competitive advantage to survive in intense competition. The shift in marketing paradigm towards a service-dominant logic (SDL) of exchange processes and relationships (Vargo \& Lusch, 2004, 2016) supports the wider needs of building a brand that focuses on customer experience and perceived value (Brodie, 2009; de Chernatony et al., 2011). Although much effort has been devoted to conceptualizing a branding theory or model that might assist managers in formulating a coherent branding strategy, i.e., consumer-based brand equity (CBBE), existing models have had a more specific focus, such as: 1) the traditional exchange of goods perspective or the goods-dominant logic, where physical attributes such as products, packaging, store image, distribution intensity, price deals, advertisements etc., are considered as marketing offerings; and 2) brand equity components, while disregarding the role of customer experience with service (i.e., service experience). This often results in poor adaptability especially in service-dominant brands (Çifci et al., 2016; Sarker et al., 2019) such as hotels, banks, transportation, and healthcare.

Following a systematic review of relevant literature, Sarker et al. (2019) report that Aaker (1991) and Keller (2016) are the most referenced scholars on brand equity operationalization for both goods and service-dominant brands. Similar to goods-dominant brand equity, service-dominant brand equity studies often adopt the common components of brand equity such as perceived quality, brand awareness/association, brand image/meaning, brand loyalty, and overall brand equity. However, the role of service experience and perceived value is either unnoticed or less emphasized in the service-dominant brands setting. For instance, Keller's (1993) CBBE model exerts a simplistic and static inter-construct relationship which disregards the asymmetry and causal complexity of CBBE (Chatzipanagiotou et al., 2016; Sarker et al., 2019). Aaker's (1991) model, on the other hand, which was operationalized by Yoo et al. (2000) using tangible product brands, ignores the perceived quality component as a symbolic aspect of brand dimension and has poor validity in service settings (Çifci et al.,

\footnotetext{
* Corresponding author. Department of Marketing, Sunway University Business School, Sunway University, 47500, Bandar Sunway, Subang Jaya, Malaysia.

** Corresponding author. Department of Marketing, Faculty of Business and Accountancy, University of Malaya, 50603, Kuala Lumpur, Malaysia.

E-mail addresses: mrajib.sarker@gmail.com, msarker@sunway.edu.my (M. Sarker), amrul_asraf@um.edu.my (A.A. Mohd-Any), yusniza@um.edu.my (Y. Kamarulzaman).
} 
2016; Nam et al., 2011). Although Aaker (1991, 1996) highlights the importance of perceived quality, it was conceptualized as a unidimensional global measure in his model. The use of such measure has, indeed, been widely criticized for the lack of depth where measurement theory is concerned (Dagger et al., 2007; MacKenzie et al., 2011). Also, the conceptualization of brand awareness and association as a single construct in Yoo et al. (2000) has been equally questioned (Pappu and Quester, 2017). As a result, Çifci et al. (2016) propose an alternative brand equity model for fashion brands comprising of brand awareness and physical quality along with three other constructs related to symbolic consumption (lifestyle congruence, brand identification, self-congruence). Nevertheless, the model ignores consumer touchpoints in services (such as servicescapes, employee service, service delivery process) and customer perceived value of the brand, which limits its potential for generalization to other service sectors.

Considering SDL view, which explicates a collaborative, value cocreation activity of all the stakeholders in the entire marketing system (Vargo and Lusch, 2016), Berry's (2000) service branding model is highly relevant (Brodie and de Chernatony, 2009). However, the absence of perceived value and the missing link between direct service experience and brand awareness leave rooms for improvement (Sarker et al., 2019). Although Berry (2016) revisits his own model and suggests the essential role of service convenience as a direct service experience component, the interrelationships among the constructs were not empirically tested. García et al. (2012) tested Berry's model in the context of destination brand by incorporating indirect service experience component only and the effect of direct service experience was disregarded. Whereas, So and King (2010) applied Berry's model in a hotel brand setting; nevertheless, a unidimensional approach of measuring direct service experience might offer limited insights in creating a strong service brand equity. In addition, although marketing scholars have acknowledged and stressed the importance of brand consistency in building brand equity [see Aaker (1996); Beverland et al. (2015); de Chernatony and Cottam (2006); Erdem and Swait (1998); Keller (2012); Polonsky and Jevons (2009)], little empirical evidence is available. Thus, the existing service branding models require a more rigorous empirical testing (Brodie et al., 2009; Pinar et al., 2016). Addressing these drawbacks, Sarker et al. (2019) propose an alternative service branding theory called the consumer-based service brand equity (CBSBE) model based on direct service experience. This model accounts for the crucial role of direct service experience, brand consistency, and perceived value along with brand awareness and brand meaning in building service brand equity in the context of airlines. However, the theoretical model of measuring service brand equity in Sarker et al. (2019) is not empirically tested with quantitative data. While Sarker et al.'s effort offers a fundamental idea concerning the relationships among the service brand equity components, a detailed discussion is necessarily required to conceptualize and operationalize the nature and directions of relationships between the constructs in the model while simultaneously examining its parsimony and validity.

Evidence shows that there were over 4.5 billion global air passengers in 2019 (Statista, 2020), contributing 873 billion US dollars to the global GDP (IATA, 2020). Despite this massive figure, the profitability rates for the last five years is minimal due to fierce competition (IATA, 2020). This trend is threatening the financial stability of the airline sector (Khan et al., 2019; Koklic et al., 2017). Furthermore, the global pandemic, COVID-19, has caused a serious turbulence to the airline industry. CAPA (2020) projected that about half of the global airlines will be wiped out; while a nationalistic aero-political confrontation is expected to support the airline industry during the 'post-coronavirus' regime. Apart from the support from national governments, airline operators will have to explore alternative avenues to overcome this challenge. From the management side, there is an apparent need for airline companies to rethink and revive their traditional strategies in order to secure a desired brand position [i.e., Adapa and Roy (2017)]. Scholars have reported a positive association between brand equity and company's profitability, and financial sustainability can be achieved in the long-run by building a strong brand equity (Mizik, 2014). Hence, building a strong brand would be a timely strategy for airlines to mitigate the complex challenges and survive in the future. However, a suitable service branding strategy for the airline industry is still scarce. Although a few studies have investigated the brand equity of airlines (Chen and Tseng, 2010; Thakshak, 2018), they have offered largely inconclusive guidelines for managers due to the missing role of airline service direct experience components in creating brand equity (Sarker et al., 2019). One may therefore argue that, airline service branding from a consumer standpoint is narrowly addressed in these models.

We mitigate these drawbacks by investigating and validating the CBSBE model in Sarker et al. (2019) which: 1) highlights the crucial role of direct service experience for creating airline brand equity; 2) advances the theoretical foundation of Berry's (2000) service branding, by incorporating brand consistency and perceived value as important brand equity components; and 3) has its robustness validated with advanced quantitative techniques (Hair et al., 2019b; Sarstedt et al., 2019). The proposed model focuses only on direct service experience because the effect of indirect experience such as communication experience on branding has been well recognized in the literature and its effect on brand equity has also been found to be symmetrical across product and service categories (Buil et al., 2013b; S. Kim et al., 2016). Berry et al. (2006) note that consumers evaluate services based on the various clues rooted in service performance rather than objects. Hence, there is reason to believe that consumers' perceived differences between products and services are not deduced through indirect experiences. We also acknowledge the effect of communication experience on brand equity as being uniform in relation to product and service brands and narrow the scope only to the direct service experience. Hence, the operationalization and validation of a new service branding model would advance the existing brand equity literature while providing useful insights for airline service practitioners.

\section{Literature review and theoretical framework}

\subsection{Service brand equity (SBE)}

Although there is no universally accepted definition of brand equity (Baalbaki and Guzmán, 2016), the definitions offered by Aaker (1991) and Keller (1993) have gained wider acceptance. Aaker (1991) conceives brand equity as a blend of actual or perceived assets and liabilities aligned with a brand, which is a source of competitive advantage from a behavioral perspective. Keller (1993, p. 8) defines it as "the differential effect of brand knowledge on consumer response to the marketing of the brand". Furthermore, Berry $(2000,2016)$ has conceptualized brand equity as a behavioral response to the value-creating activities of the offered brand. Based on these views, we define service brand equity as the consumer's differential response to the value co-creation activities of the presented brand based on the experience gained.

Pioneered by Yoo et al. (2000), brand equity as a construct is conceptualized as a behavioral outcome indicating the incremental response of consumers. In other words, a favorable assessment of brand equity components leads to a positive consumer behavioral response. In the airline setting, a strong airline brand generally enjoys an incremental preference over other airlines when it comes to ticket booking. In this regard, a pleasant travel experience on previous occasions together with a favorable brand position in the current market, might induce passengers to have a strong preference for an airline over another. Berry (2000) postulates that the purchase of a service brand by consumers depends on a favorable brand meaning and a higher level of brand awareness. Eventually, a higher level of brand equity would result in a positive incremental response (Buil et al., 2013a; Na et al., 1999). Thus, a positive service brand equity of an airline will emerge when passengers' preference for flying with that airline is incrementally higher than other airlines. For this reason, creating a positive service brand equity is 
essential in the highly competitive airline market.

\subsection{Theoretical foundation}

Previous brand equity (BE) research [see Buil et al. (2013a); Chen and Tseng (2010); Konecnik and Gartner (2007)] adopts the traditional cognitive response hierarchy by Lavidge and Steiner (1961) to explain the causal relationship between brand equity constructs. Past studies also indicated that brand awareness (a cognitive component) positively affects brand image and perceived quality (affective components), which subsequently affect brand loyalty and brand equity (conative components). However, the conceptualized relationship of brand awareness with other BE constructs during the initial stage is debatable. As brand awareness is the ability to recall and recognize brand stimuli (Aaker, 1991; Keller, 1993), without prior contact with any direct and indirect stimuli of an object, learning or recalling information (e.g., the brands' attributes) would be difficult (van Osselaer and Janiszewski, 2001). It is also evident that brand awareness is attributed to consumer experience, with a myriad of brand touchpoints (Lemon and Verhoef (2016). We, therefore, propose a refined BE model where experience touchpoints are introduced at the early stages. We further adopt the Stimulus-Organism-Response (S-O-R) hierarchy of Mehrabian and Russell (1974) and Jacoby (2002) to explain our model.

Stimuli (S) are the cues of consumer touchpoints that are understood to be external to individuals, encompassing "products, brands, logos, ads, packages, prices, stores and store environments, word-of-mouth communications, newspapers, television ..." and "implicit learning and learning without awareness" (Jacoby 2002, p. 54). The components of direct service experience are external to the consumers and are under the control of service providers in the form of value offerings. Brand consistency, in a similar vein, is a consumer's concurrent assessment of the experience components. Therefore, direct service experience components and brand consistency are classified as stimuli in our study. Organism $(\mathrm{O})$ is the assessment of stimuli understood to be internal to the individual and "the storehouse of the individual's emotive and cognitive systems, including all retained prior experiences, and is generally referred to as long-term memory" (Jacoby 2002, p. 54). Hence, our brand equity components, i.e., brand awareness, brand meaning, and perceived value are classified as organismic elements. Finally, according to (Jacoby 2002, p. 55), response (R) refers to "the physical and physiological responses, smiles, communicative acts, as well as the acquisition, usage, storage and disposal of products, services, time, and ideas". Response behavior includes consumer's positive and negative responses in the form of buying, future buying intention, and sharing the brand experience (Ul Islam and Rahman, 2017). Since service brand equity in this research refers to consumers' differential response vis-à-vis the presented brand stimuli, it is classified here as a response component. Therefore, align with S-O-R hierarchy, we propose that airline service direct experience (ASDE) affects brand consistency, brand awareness, brand meaning and perceived value, which in turn influence the service brand equity. Besides, brand consistency affects the brand equity components such as brand awareness, brand meaning, and perceived value.

\subsection{Hypotheses development}

\subsubsection{Airline service direct experience (ASDE) and brand equity components}

Consumer touchpoints are external stimuli which cultivate individual experience (Österle et al., 2019) in every stage of the engagement with a company and its activities (Holmlund et al., 2020; Lemon and Verhoef, 2016). Compared to tangible-dominant brands, consumer direct experience with services is crucial due to the involvement of multiple actors and touchpoints in service encounters (Grönroos and Gummerus, 2014; Krystallis and Chrysochou, 2014). For this reason, consumer's assessment of service experience is deeply rooted in direct service encounters rather than indirect touchpoints (Berry et al., 2006). From a services marketing perspective, service experience is considered as drama. Hence, the theatrical concept and philosophies would be appropriate to define the components of service experience, consisting of actors (service employees), audience (final consumers), physical setting (servicescapes), and process (access to service) (Grove et al., 1998). Within this conceptualization, consumers encounter direct contacts with the provider during the purchase process initiated by themselves. Therefore, decision convenience and access convenience are relevant to the current conceptualization of direct service experience.

In the context of airline service, passengers experience direct service experience through searching for travel-related information on the airline's website, booking a ticket, boarding the aircraft, and reaching the destination airport. Here, they encounter at least five service touchoints which are purchase decision experience (decision convenience), airport service experience (access convenience), employee service (interaction with employee), in-flight core service (servicescapes), and interaction with other passengers (audience), called the airline service direct experience (ASDE).

Empirical studies show that service experience components are positively related to consumers' cognitive and emotional responses (Ali et al., 2016; Bitner, 1992; Gil et al., 2008). Thus, ASDE has a positive effect on brand equity constructs. According to the S-O-R paradigm, external stimuli passes through an internal evaluation of consumer assessment, which forms a positive long-lasting impression. For this reason, enjoyable experience with ASDE indicates a positive influence on the assessment of level of consistency over the service experience journey i.e., brand consistency (BC). However, empirical investigations on these two variables are sparse, even in airline service. Belboula and Ackermann (2019) assert that the tangible experience attributes of a service are crucial in creating brand meaning. So and King (2010) examined the influence of direct service experience with brand meaning $(\mathrm{BM})$ in a hotel setting and reported a positive and strongest effect. Berry (2000, 2016) notes that BM is the overall impression about a brand's attribute, which is the dominant source for creating service brand equity. Besides, the ability to recall and recognize the brand i.e., brand awareness (BA) is related to the previous exposure of experience touchpoints (Cowley, 2007). Although Lemon and Verhoef (2016) stress the role of direct experience encounters in formulating consumers' understanding, knowledge, perception, and feelings, the relationship between direct service experience and BA has been largely disregarded in existing research. In a service branding context, we argue that perceived value (PV) is central to brand equity creation, which is deeply grounded in the direct experience touchpoints [see Kumar and Reinartz (2016); Roy et al. (2019)]. Although the relationship between direct service experience and perceived value is recognized in the literature (Mitchell et al., 2016; Verhoef et al., 2009), empirical investigation related to service brand equity construction is still sparse. The above discussions, therefore, lead to the following hypotheses:

H1. Airline service direct experience has a positive effect on brand consistency

H2. Airline service direct experience has a positive effect on brand awareness

H3. Airline service direct experience has a positive effect on brand meaning

H4. Airline service direct experience has a positive effect on perceived value

\subsubsection{Brand consistency $(B C)$ and brand equity components}

Brand Consistency refers to "the degree to which each mix component or decision reflects the intended whole" (Erdem and Swait 1998, p. 137). It is conceptualized as sharing a unique theme of customer experience derived through brand touchpoints. Marketers offer value to the consumer through the marketing mix elements which are consumed by 
the end user (Kotler and Armstrong, 2017). Thus, consumer experience encompasses all the direct and indirect touchpoints through which consumers perceive value as being offered to them. In a service experience journey like airline, passengers' experience is not only confined to the airport and onboard service; instead, it begins from the moment they book a ticket and continues until they leave the destination airport (Grönroos, 1984). Consistency in delivering the promised services in each encounter signals the ability of a brand to perform optimally in future (Erdem and Swait, 2016). Previous literature has affirmed the importance of consistency in influencing brand asset perceptions (Kapferer, 2008; Keller, 2012). Due to the inherent nature of services being heterogeneous (Lovelock and Gummesson, 2004), ensuring consistent performance in each service encounter is certainly a challenge for service marketers. Erdem and Swait $(1998,2016)$ conceive brand consistency as the similarity between brand performance and previously defined perceived image, along with what is guaranteed by the companies through indirect encounters such as ads, price, and deals. Based on S-O-R hierarchy, it was argued that BC is consumers' internal assessment of a brand in the short-run, which also influences their cognitive, affective, and behavioral assessments in the long-run (Jacoby, 2002). Thus, the perceived brand consistency of an airline brand will be high when passengers experience the promised level of service in each ASDE encounter. Subsequently, the high level of consistency across the airline service (S) is expected to increase the brand equity component of the airline $(\mathrm{O})$.

From a behavioral perspective, consistency across the service encounter reduces the tension and discomfort in consumers' mind, which exerts a positive evaluation towards an object (Erdem and Swait, 1998). Keller (1993) advocates that BC positively influences the level of $\mathrm{BA}$ and BM. When a brand fulfils its promise at every touchpoint, the consistency results in authenticity and perceived importance (Schallehn et al., 2014). Erdem and Swait $(1998,2016)$ also assert that a higher level of BC is positively associated with higher levels of brand credibility and clarity. This supports the findings in Delgado-Ballester et al. (2012) that, congruence between communications and brand performance strengthen brand asset elements such as brand awareness, brand association, and favouribility of brand attitudes. Y. Liu et al. (2017) also experimented on the BC of luxury car brands to explain consumers' ability to recognize brands and reported positive outcomes. Hence, we posit the essential role of $\mathrm{BC}$ on brand asset components as follows:

H5. Brand consistency positively influences brand awareness

H6. Brand consistency positively influences brand meaning

H7. Brand consistency positively influences perceived value

\subsubsection{Brand equity components (i.e., brand awareness, brand meaning and} perceived value) and service brand equity

Brand awareness (BA) is defined as the ability of consumers to recall and recognize a specific brand under a given condition (Aaker, 1991; Keller, 1993). Cowley (2007) asserts that BA is consumers' memory that is informed by their previous experience with a brand. Hence, we argue that a recalled and well-recognized brand does not necessarily guarantee quality, but a pleasant experience with the brand might do. Berry (2000, 2016) stress that the effect of BA in creating SBE varies between experienced and inexperienced consumers. For experienced consumers, BA plays a secondary role in persuading consumer response. Studies such as Chen and Tseng (2010), Bianchi et al. (2014), and Kotsi et al. (2018) suggest a significant positive relationship between BA and brand equity, while others (M. T. Liu et al., 2017; Rodrigues et al., 2016; So and King, 2010) describe a positive, but insignificant path.

Brand meaning (BM) refers to consumers' overall impression of a brand's positioning and its associations (Berry, 2000). Keller (1993) asserts that attributes, benefits, and attitudes associated with brands should possess favorability, strength, and uniqueness, which trigger BM. Berry $(2000,2016)$ also postulates that an experience-based belief is key to branding services and plays an important role in building service brand equity for experienced consumers. For example, in a service setting like airlines, consumers may have limited or non-existent experience-based clues for assessing an airline before coming into contact with the ASDE. Thus, passengers' experience-based belief is more active in eliciting a positive differential response to the airline brand relative to others. Several studies have shown that BM has the highest positive and significant effect on destination (García et al., 2012) and hotel brand equity (Šerić et al., 2017; So and King, 2010). Similarly, BM has a positive and significant effect on financial service brand equity (Pinar et al., 2016) and hospital brand equity (Wang et al., 2011).

Previous studies have claimed that perceived value (PV) is central to consumers' preference and behavior (Grönroos and Gummerus, 2014; Leong et al., 2018) and is regarded as an essential component of brand equity and an antecedent of loyalty (Lam et al., 2010; Lassar et al., 1995). However, only a handful [i.e., K. Kim et al. (2008b); Liu et al. (2015)] have reported mixed causal relationships among the constructs. PV refers to consumers' affective evaluation of a brand based on what is received (perception about the utility of service features) and what is sacrificed (perception about momentary and non-monetary costs) (Zeithaml, 1988), and is often viewed as overall value, benefits and attributes, and the relative standing of the benefits/attributes (Kumar and Reinartz, 2016). W. G. Kim et al. (2008) elucidate the relationships between brand equity components in a hotel brand setting and note that PV has the largest positive influence on behavioral response. Similarly, Brodie et al. (2009) suggest a strong positive significant effect of PV on consumer response. Other studies have highlighted the significant effect of PV on destination brand equity (Kotsi et al., 2018; Pike and Bianchi, 2016) and purchase intention of private label brand (Walsh and Mitchell, 2010). Despite its importance in brand equity formation, Berry's (2000, 2016) work did not include PV. We address this gap by suggesting that experience-based perception of value is central to branding airline services.

Therefore, in line with the S-O-R hierarchy in Jacoby (2002) where brand awareness, brand meaning, and perceived value in this study are classified as organism $(\mathrm{O})$ and service brand equity as response $(\mathrm{R})$, the above arguments lead to the following hypotheses:

H8. Brand awareness positively influences the service brand equity.

H9. Brand meaning positively influences the service brand equity.

H10. Perceived value has the highest positive influence on service brand equity when comparing the relationships with brand awareness and brand meaning.

Overall, we argue that direct service experience is a key element for strengthening the brand equity/asset components, which subsequently increase service brand equity. Among the brand equity/asset components (i.e., brand awareness, brand meaning, and perceived value) influencing consumer response (i.e., SBE), perceived value is recommended to dominate the creation of positive service brand equity. Thus, consumer experience-based perception of value is deemed to be the nucleus of branding airline services as shown in Fig. 1.

\section{Methodology}

\subsection{Sampling}

To test and validate our proposed model in the airline context, only passengers with full-service international flight experience were the target respondents. This is due to the significant difference on the level of services provided and experiences obtained between full-service airlines and low-cost airlines. Low-cost airlines are also known as no-frills airlines which emphasize on low fares as main selling point, with less services, limited amenities and fewer comforts (Koklic et al., 2017). Hence, passengers with full-service international flight experience were the appropriate sampling unit in this study. As airline companies 


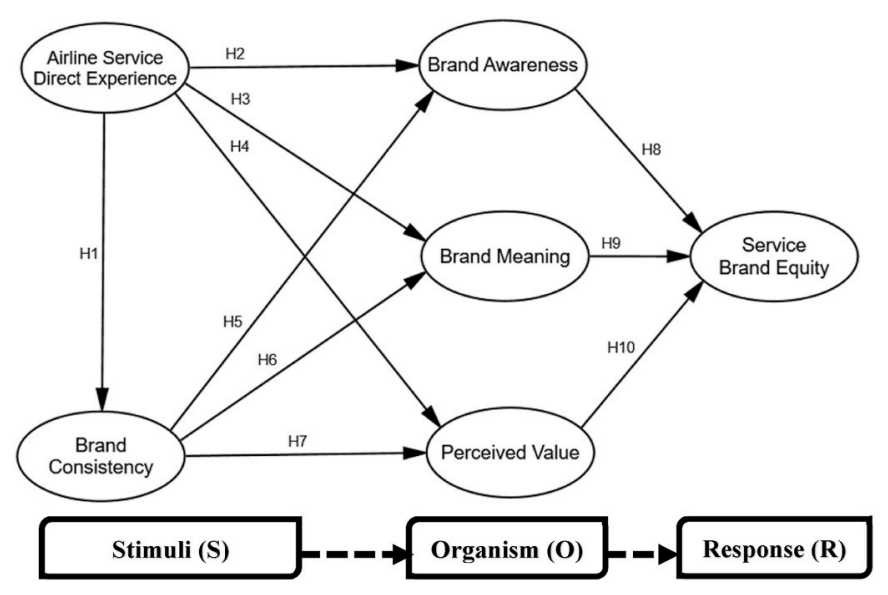

Fig. 1. Theoretical framework of CBSBE.

operating throughout the world provide similar services even in multiple destinations (Jun et al., 2010), any international airport is a suitable location for data collection. In this case, we chose Kuala Lumpur International Airport 1 (KLIA1) in Malaysia which handles only fully-fledged airlines. Malaysia was ranked second among the South-East and Southern Asian countries for preferred travel destination in 2019 after Singapore (World Economic Forum, 2020). Tourism Malaysia (2019) recorded about 25.8 million international arrivals in Malaysia in 2018. This statistics implies the presence of a significant number of international tourists in Malaysia. Besides, as the main international airport in the country, KLIA1 is the busiest with about $84 \%$ air traffic in 2018 (MAHB, 2019). Since all full-service international airlines use this airport terminal, access to passengers was not an issue, making KLIA1 the best location for an airport intercept survey.

A two-stage sampling process was adopted to select the respondents. Firstly, top-ranked and well-reputed airlines operating in KLIA1 were targeted (Buil et al., 2013a) with the list derived from SKYTRAX (2019). Secondly, respondents were solicited based on two essential criteria: (a) they must have flight travel experience in the last six months, and (b) they must fly with any one of the airlines in the list; these were provided as screening questions.

\subsection{Measurement and survey instrument}

A structured questionnaire was designed to indicate our study variables and respondents' demographic information. The study variables were measured using validated scales derived from previous literature (see Table 1). All items were rated on a 7-point Likert-type scale with “

Table 1

Sources of measurement scale.

\begin{tabular}{|c|c|c|c|}
\hline No & Constructs & $\begin{array}{l}\text { No. of } \\
\text { items }\end{array}$ & Sources \\
\hline \multirow[t]{6}{*}{1} & $\begin{array}{l}\text { Airline service direct } \\
\text { experience (ASDE) }\end{array}$ & & \\
\hline & $\begin{array}{ll}\text { a } & \text { Purchase decision } \\
\text { experience }(P D)\end{array}$ & 4 & Thuy (2011) \\
\hline & b Employee service (ES) & 7 & Grace and O'Cass (2005) \\
\hline & Inflight core services (CS) & 8 & Han et al. (2014) \\
\hline & $\begin{array}{l}\text { Airport service experience } \\
\text { (AS) }\end{array}$ & 4 & Thuy (2011) \\
\hline & $\begin{array}{ll}\boldsymbol{e} & \text { Interaction with other } \\
\text { passengers }(\mathrm{OP})\end{array}$ & 4 & Brocato et al. (2012) \\
\hline 2 & Brand consistency (BC) & 6 & Erdem and Swait (1998) \\
\hline 3 & Brand awareness (BA) & 6 & Yoo et al. (2000) \\
\hline 4 & Brand meaning (BM) & 4 & García et al. (2012) \\
\hline 5 & Perceived value (PV) & 6 & Karpen et al. (2015) \\
\hline 6 & Service brand equity (SBE) & 5 & $\begin{array}{l}\text { Chen and Tseng (2010) and } \\
\text { Yoo et al. (2000) }\end{array}$ \\
\hline
\end{tabular}

1 = Strongly disagree" and "7 = Strongly agree". The questionnaire was designed in English since the target respondents were international passengers. To ensure content validity, the questionnaire was pre-tested following the debriefing and protocol method in Hunt et al. (1982) with eight experts (five academics and three professionals) and eleven participants who are frequent international travelers; and minor revisions were made based on their feedback.

Due to the variation and complexity in the direction of causation and estimation method in our model (see Fig. 1), it is important to define whether the measurement model is of a reflective or formative nature (Coltman et al., 2008). Misspecification between a reflective and a formative model may cause estimation biases when latent variables are measured (MacKenzie et al., 2011). Our CBSBE model consists of six latent variables in which ASDE was operationalized as a higher-order formative construct with five reflectively measured lower-order components (i.e., PD, ES, CS, AS, and OP) [see Ali et al. (2016); Grace and O'Cass (2005); Krystallis and Chrysochou (2014)]. All other variables were measured reflectively in accordance with the literature.

\subsection{Data collection}

Data were collected by a team consisting of five enumerators who were trained by the researchers for carrying out an airport intercept survey in KLIA1. The team was divided into two groups and stationed at the international arrival and departure halls. The survey was administered in the public area, encompassing the waiting, walking, and resting places of both halls. A self-administered questionnaire was distributed to airline passengers who agreed to complete the survey and met our selection criteria above (Batouei et al., 2019). Around 2500 respondents were approached over a period of two weeks, and a total of 778 questionnaires were returned with $31 \%$ response rate, which is similar to past studies using airport intercept [see Smahel (2017)]. Since the study targets only passengers of fully-fledged airlines from the SKYTRAX's list, a general note in the cover letter with the list of airlines were included in the screening section of the questionnaire. Respondents were required to answer the questions based on their experience derived from any one airline they select from the list provided. This important requirement was also explained verbally when approaching them. Despite these efforts, a total of 77 respondents still rated their airline travel experience with low-cost airlines. Due to this and other 49 incomplete responses received, 126 questionnaires were discarded, resulting in 652 useable responses. To confirm whether these responses were statistically sufficient, the $G^{*}$ Power software version 3.1.9.2 (Faul et al., 2009) was used to calculate the minimum sample size (Hair et al., 2017). To achieve a $95 \%$ power with effect size of 0.15 and $\alpha$ probability of 0.01 , the calculated minimum sample size was 180 . This shows that a total of 652 usable responses were far above the minimum requirement, demonstrating a satisfactory level of sample size. The respondents' profile is shown in Table 2.

The initial pool of data was analyzed for missing values, which showed that $0.031 \%$ values were missing (i.e., 16 cases only) and replaced by mean values (Taheri et al., 2019). Nonresponse bias was investigated for demographic variables (e.g., gender, age, income, occupation, education, region) between the early 100 and late 100 responses of the survey (Armstrong and Overton, 1977). No significant differences $(p>0.05)$ were demonstrated; hence, nonresponse bias was unlikely to be a concern in our study. The distributional assumption of the data was assessed using a web application software called 'WebPower' (available at - https://webpower.psychstat.org/models/kurto sis/). The skewness values of ES and BA and the kurtosis values of PD, $\mathrm{ES}, \mathrm{CS}, \mathrm{OP}, \mathrm{BM}$, and BA were slightly outside the range of \pm 1 . Whereas, the Mardia's coefficient of skewness and kurtosis were significant at $p<0.05$, implying the data distribution was univariate and multivariate nonnormal (Hair et al., 2017). Furthermore, the investigation of homoscedasticity using scatterplot (e.g., all scores were within \pm 3 ) and autocorrelation using Durbin-Watson (DW) statistics (e.g., $D W=$ 
Table 2

Demographic profile of the study. $(N=652)$

\begin{tabular}{|c|c|c|c|c|c|}
\hline Characteristics & No & $(\%)$ & Characteristics & No & (\%) \\
\hline \multicolumn{3}{|c|}{ How long ago in last six month? } & \multicolumn{3}{|l|}{ Marital status } \\
\hline Last month & 358 & 54.91 & Single & 319 & 48.9 \\
\hline $2-3$ months ago & 146 & 22.39 & Married & 333 & 51.1 \\
\hline 4-6 months ago & 148 & 22.7 & Region of origin & & \\
\hline \multicolumn{3}{|c|}{ Name the airline that you travelled } & African & 49 & 7.5 \\
\hline Emirates & 66 & 10.12 & Asian & 284 & 43.6 \\
\hline Qatar Airways & 65 & 9.97 & Australasian/Oceanian & 26 & 4 \\
\hline Turkish Airlines & 52 & 7.98 & European & 202 & 31 \\
\hline Singapore Airlines & 50 & 7.67 & Middle Eastern & 54 & 8.3 \\
\hline Thai Airways & 49 & 7.52 & North American & 34 & 5.2 \\
\hline Etihad Airways & 44 & 6.75 & South American & 3 & 0.5 \\
\hline Garuda Indonesia & 41 & 6.29 & \multicolumn{3}{|c|}{ Highest educational qualification } \\
\hline $\begin{array}{l}\text { ANA All Nippon } \\
\text { Airways }\end{array}$ & 38 & 5.83 & $\begin{array}{l}\text { Secondary School and } \\
\text { lower }\end{array}$ & 29 & 4.45 \\
\hline KLM & 38 & 5.83 & Diploma/Certificate & 139 & 21.32 \\
\hline Lufthansa & 38 & 5.83 & Bachelor's Degree & 278 & 42.64 \\
\hline Cathay Pacific & 34 & 5.21 & Master's Degree & 175 & 26.84 \\
\hline Malaysia Airlines & 32 & 4.91 & $\mathrm{PhD}$ & 31 & 4.75 \\
\hline Air France & 31 & 4.75 & \multicolumn{3}{|l|}{ Occupational category } \\
\hline Japan Airlines & 30 & 4.6 & Clerical & 33 & 5.1 \\
\hline China Southern & 20 & 3.07 & Supervisory/Executive & 112 & 17.2 \\
\hline British Airways & 12 & 1.84 & Management & 139 & 21.3 \\
\hline EVA Air & 12 & 1.84 & $\begin{array}{l}\text { Professional (e.g., Doctor, } \\
\text { Engineer, Teacher etc.) }\end{array}$ & 199 & 30.5 \\
\hline \multicolumn{3}{|l|}{ Gender } & \multicolumn{3}{|l|}{ Business } \\
\hline Male & 358 & 54.9 & Not Working/Retired & 17 & 2.6 \\
\hline Female & 294 & 45.1 & Student & 45 & 6.9 \\
\hline \multicolumn{3}{|l|}{ Age (years) } & Homemaker & 16 & 2.5 \\
\hline $18-29$ & 243 & 37.3 & \multicolumn{3}{|c|}{ Annual household income (USD) } \\
\hline 30-39 & 197 & 30.2 & Less than $\$ 10,000$ & 144 & 22.09 \\
\hline $40-49$ & 107 & 16.4 & $\$ 10,000-\$ 29,999$ & 151 & 23.16 \\
\hline $50-59$ & 77 & 11.8 & $\$ 30,000-\$ 49,999$ & 131 & 20.09 \\
\hline $60-69$ & 19 & 2.9 & $\$ 50,000-\$ 69,999$ & 81 & 12.42 \\
\hline \multirow[t]{2}{*}{70 or above } & 9 & 1.4 & $\$ 70,000-\$ 99,999$ & 71 & 10.89 \\
\hline & & & $\$ 100,000$ or above & 74 & 11.35 \\
\hline
\end{tabular}

1.81 which is between 1.5 and 2.5) demonstrated that assumptions of linearity and independence of error in the dataset are met (Sarstedt and Mooi, 2019).

\subsection{Common method bias (CMB)}

As data were collected from a single source using similar measurement method for both the exogenous and endogenous variables, we took the necessary steps to control and investigate CMB using the two common approaches, i.e., the procedural and statistical remedies (Podsakoff et al., 2003). For the procedural remedies, a psychological/temporal separation between exogenous and endogenous variables was done by not placing the items measuring dependent variable immediately after the items measuring the independent variables; they were separated using psychographic variables [see Podsakoff et al. (2003); Svensson et al. (2018)]. For the statistical remedies, two methods for determining the presence of common method variance (CMV) were applied: 1 ) the Harman's single factor test, with a $43.75 \%$ variance explained, which is less than 50\% (Fuller et al., 2016; Svensson et al., 2018); and 2) the measured latent marker variable (MLMV) approach (Chin et al. (2013), with a four-item scale measuring "compensation" in Bal et al. (2013) included in the questionnaire, which is theoretically unrelated to the study variables. The results show that all estimations linking the study constructs with the MLMV were far lower than the cut-off value of $10 \%$ (Chin et al., 2013; Oliveira and Handfield, 2019), indicating that CMB was not an issue in our study.

\subsection{Analytical approaches}

Due to model complexity (i.e., 10 latent variables and 54 indicators) with a formatively measured construct (i.e., ASDE) and the absence of normality (Hair et al., 2019a) as discussed above, PLS-SEM technique with SmartPLS 3.2.9 was deemed suitable for this study.

The evaluation involves a two-stage process via measurement model assessment and structural model evaluation (Hair et al., 2020). Before evaluating the quality of the measurement model, a test of measurement invariance needs to be conducted as measurement error in the overall dataset could inflate the estimations and decrease the precision of results (Hult et al., 2008). Hence, the data was divided randomly into two groups using SPSS v23, and called the calibration group $[n=324]$ and the validation group $[n=328]$ (Byrne, 2016). They were then analyzed following the measurement model invariance assessment technique (MICOM, for short) in Henseler et al. (2016). If any variances emerged between the calibration and the validation groups, the data cannot be pooled into a single group, and therefore, a multigroup analysis should be used to examine the structural model (Henseler et al., 2016). In contrast, if the measurement properties between the calibration and validation groups are completely invariant, the pooled data can be analyzed as a whole single dataset. Next, as one of our study objectives is to examine the robustness of the proposed CBSBE model, the following statistical procedures were also performed: predictive accuracy, nonlinearity, endogeneity, and unobserved heterogeneity (Hair et al., 2020; Sarstedt et al., 2019).

\section{Results and findings}

\subsection{Measurement model analysis}

\subsubsection{Measurement invariance test}

To perform MICOM, there are three sets of criteria to fulfil. Firstly, the configural invariance (Criteria 1). Since the identical PLS path models and algorithm set-ups were configured for both calibration and validation groups, we can confirm that the first criterion was certainly met. Secondly, for Criteria 2, the original correlation scores were compared with the empirical correlation scores using 5000 permutations. The results confirmed that the original composite scores (original correlations) were higher than the empirical composite scores ( $5 \%$ quantile) in all ten constructs, implying the presence of partial invariance. Thirdly, for Criteria 3 , the full measurement invariance was also examined by comparing the composite means and variances of two groups, again using 5000 permutations. The results in Table 3 show a full measurement invariance as the differences in composite means and variances between the two groups are statically insignificant $(p>0.05)$. Also, a 'zero' remains present in the $95 \%$ BCa CIs of the ten latent constructs. Hence, it can be argued that the measurement models are completely invariant across the randomly divided two groups, thus the data were pooled in a single set $(N=652)$ for further analysis (Henseler et al., 2016; Svensson et al., 2018).

\subsubsection{Measurement model assessment}

Guided by the standard evaluation criteria [see Hair et al. (2020); Hair et al. (2019a)], the ten first-order reflective constructs were examined for internal consistency reliability, convergent validity, and discriminant validity.

The internal consistency via composite reliability (CR) ranges between 0.883 and 0.940 , which are consistently higher than the recommended threshold of $>0.70$, indicating satisfactory level of internal consistency reliability. Out of a total of 54 indicators, the lowest loading is PD1 (0.681), while the highest loading is OP4 (0.899). Although the indicator loading of PD1 is lower than the threshold, the average variance extracted (AVE) of purchase decision experience (PD) exceeds the minimum level of $>0.50$. Hence, PD1 was retained (Hair et al., 2017). With all AVE values ranging from 0.599 to 0.759 , convergent validity was affirmed (Table 4).

Discriminant validity of the latent variables (Table 5) was examined in line with the Heterotrait-Monotrait (HTMT) ratio of correlations guidelines in Franke and Sarstedt (2019); Henseler et al. (2015). None of 
Table 3

Assessment of measurement invariance between calibration and validation sample groups.

\begin{tabular}{|c|c|c|c|c|c|c|c|c|c|c|}
\hline \multirow[t]{2}{*}{ Constructs } & \multirow{2}{*}{$\begin{array}{l}\text { Configural } \\
\text { invariance? }\end{array}$} & \multicolumn{2}{|c|}{ Compositional invariance (Correlation $=1$ ) } & \multicolumn{3}{|c|}{ Equal mean assessment } & \multicolumn{3}{|c|}{ Equal variance assessment } & \multirow{2}{*}{$\begin{array}{l}\text { Full measurement } \\
\text { invariance } \\
\text { established? }\end{array}$} \\
\hline & & Original correlation & $5.0 \%$ quantile & Differences & $95 \% \mathrm{BCa} \mathrm{CI}$ & Sig & Differences & $95 \%$ BCa CI & Sig & \\
\hline AS & Yes & 0.9997 & 0.9989 & 0.028 & {$[-0.152,0.156]$} & 0.729 & 0.039 & {$[-0.261,0.263]$} & 0.777 & Yes \\
\hline BA & Yes & 0.9992 & 0.9988 & 0.024 & {$[-0.153,0.156]$} & 0.762 & -0.115 & {$[-0.291,0.291]$} & 0.434 & Yes \\
\hline BC & Yes & 0.9999 & 0.9996 & 0.074 & {$[-0.152,0.152]$} & 0.348 & -0.068 & {$[-0.267,0.274]$} & 0.629 & Yes \\
\hline $\mathrm{BM}$ & Yes & 0.9998 & 0.9997 & 0.083 & {$[-0.157,0.154]$} & 0.299 & -0.019 & {$[-0.286,0.297]$} & 0.905 & Yes \\
\hline CS & Yes & 0.9998 & 0.9996 & 0.055 & {$[-0.149,0.153]$} & 0.486 & -0.116 & {$[-0.282,0.275]$} & 0.419 & Yes \\
\hline ES & Yes & 1.0000 & 0.9996 & 0.048 & {$[-0.151,0.158]$} & 0.546 & -0.159 & {$[-0.322,0.326]$} & 0.358 & Yes \\
\hline OP & Yes & 1.0000 & 0.9993 & 0.079 & {$[-0.158,0.154]$} & 0.314 & -0.063 & {$[-0.268,0.275]$} & 0.652 & Yes \\
\hline $\mathrm{PD}$ & Yes & 0.9995 & 0.9982 & 0.072 & {$[-0.151,0.149]$} & 0.360 & -0.033 & {$[-0.267,0.271]$} & 0.812 & Yes \\
\hline PV & Yes & 1.0000 & 0.9996 & 0.058 & {$[-0.154,0.149]$} & 0.477 & 0.026 & {$[-0.231,0.236]$} & 0.829 & Yes \\
\hline SBE & Yes & 0.9999 & 0.9998 & 0.116 & {$[-0.152,0.151]$} & 0.144 & 0.049 & {$[-0.254,0.259]$} & 0.708 & Yes \\
\hline
\end{tabular}

Note: $\mathrm{AS}=$ Airport service experience; $\mathrm{BA}=$ Brand awareness; $\mathrm{BC}=$ Brand consistency; $\mathrm{BM}=$ Brand meaning; $\mathrm{CS}=$ In-flight core service; $\mathrm{ES}=\mathrm{Employee} \mathrm{service;} \mathrm{OP}=$ Interaction with other passengers; $\mathrm{PD}=$ Purchase decision experience; $\mathrm{PV}=$ Perceived value; $\mathrm{SBE}=$ Service brand equity. $\mathrm{BCa} \mathrm{CI}=\mathrm{Bias}$-corrected and accelerated confidence interval.

the values exceed the stringent HTMT value of 0.85 , thus confirming discriminant validity.

Lastly, the measurement properties of formative construct (i.e., ASDE) were assessed based on, 1) indicators' multicollinearity, 2) the size and significance of indicators' weight, and 3) convergent validity with single global item (Hair et al., 2020). The variance inflation factor (VIF) of the formative indicators are between 1.564 and 2.333 (see Table 4), which is clearly below the critical value of 3.3 (Diamantopoulos and Siguaw, 2006), indicating that multicollinearity was not an issue for concern. Besides, all the outer weights of formative indicators show significance at 95\% BCa CI. The convergent validity of ASDE is also assured as the path coefficient with single global item $(\beta=0.683)$ was slightly lower than 0.70 , but exceeded the desirable cut-off value of 0.60 (Ramayah et al., 2018). Therefore, these imply that our proposed ASDE satisfies the benchmarks for a formative construct.

\subsection{Structural model analysis}

\subsubsection{Hypotheses testing}

Fig. 2 and Table 6 illustrate the path relationships of our CBSBE

Table 4

Reliability and convergent validity of study constructs.

\begin{tabular}{|c|c|c|c|c|c|c|c|c|c|}
\hline \multirow[t]{2}{*}{ First-order constructs } & \multicolumn{2}{|c|}{ Reflective } & \multirow[b]{2}{*}{$\mathrm{CR}$} & \multirow[b]{2}{*}{ AVE } & \multirow[t]{2}{*}{ First-order constructs } & \multicolumn{2}{|c|}{ Reflective } & \multirow[b]{2}{*}{$\mathrm{CR}$} & \multirow[b]{2}{*}{ AVE } \\
\hline & Items & loadings & & & & Items & loadings & & \\
\hline \multirow[t]{4}{*}{ Airport Service Experience (AS) } & AS1 & 0.851 & \multirow[t]{4}{*}{0.888} & \multirow[t]{4}{*}{0.666} & \multirow[t]{4}{*}{ Brand Consistency (BC) } & BC1 & 0.857 & \multirow[t]{6}{*}{0.935} & \multirow[t]{6}{*}{0.707} \\
\hline & AS2 & 0.865 & & & & BC2 & 0.785 & & \\
\hline & AS3 & 0.704 & & & & BC3 & 0.878 & & \\
\hline & AS4 & 0.836 & & & & BC4 & 0.836 & & \\
\hline \multirow[t]{8}{*}{ In-flight Core Service (CS) } & CS1 & 0.795 & \multirow[t]{8}{*}{0.923} & \multirow[t]{8}{*}{0.599} & & BC5 & 0.806 & & \\
\hline & $\mathrm{CS} 2$ & 0.812 & & & & BC6 & 0.878 & & \\
\hline & CS3 & 0.838 & & & Brand Awareness (BA) & BA1 & 0.804 & 0.919 & 0.655 \\
\hline & CS4 & 0.725 & & & & BA2 & 0.825 & & \\
\hline & CS5 & 0.764 & & & & BA3 & 0.787 & & \\
\hline & CS6 & 0.725 & & & & BA4 & 0.774 & & \\
\hline & CS7 & 0.765 & & & & BA5 & 0.843 & & \\
\hline & CS8 & 0.764 & & & & BA6 & 0.823 & & \\
\hline \multirow[t]{7}{*}{ Employee Service (ES) } & ES1 & 0.777 & \multirow[t]{7}{*}{0.925} & \multirow[t]{7}{*}{0.637} & \multirow[t]{4}{*}{ Brand Meaning BM) } & BM1 & 0.837 & \multirow[t]{4}{*}{0.917} & \multirow[t]{4}{*}{0.735} \\
\hline & ES2 & 0.828 & & & & BM2 & 0.859 & & \\
\hline & ES3 & 0.798 & & & & BM3 & 0.846 & & \\
\hline & ES4 & 0.849 & & & & BM4 & 0.887 & & \\
\hline & ES5 & 0.792 & & & \multirow[t]{3}{*}{ Perceived Value (PV) } & PV1 & 0.883 & \multirow[t]{3}{*}{0.931} & \multirow[t]{3}{*}{0.691} \\
\hline & ES6 & 0.787 & & & & PV2 & 0.863 & & \\
\hline & ES7 & 0.751 & & & & PV3 & 0.837 & & \\
\hline Interaction with Other Passengers (OP) & OP1 & 0.831 & 0.920 & 0.742 & & PV4 & 0.821 & & \\
\hline & OP2 & 0.813 & & & & PV5 & 0.735 & & \\
\hline & OP3 & 0.897 & & & & PV6 & 0.842 & & \\
\hline & OP4 & 0.899 & & & Service Brand Equity (SBE) & SBE1 & 0.873 & 0.940 & 0.759 \\
\hline Purchase Decision Experience (PD) & PD1 & 0.681 & 0.883 & 0.655 & & SBE2 & 0.849 & & \\
\hline & PD2 & 0.814 & & & & SBE3 & 0.860 & & \\
\hline & PD3 & 0.871 & & & & SBE4 & 0.897 & & \\
\hline & PD4 & 0.858 & & & & SBE5 & 0.876 & & \\
\hline Second-order construct & Forma & & & & & & Convergent vali & & \\
\hline & Items & Weights & t-values & $95 \% \mathrm{~B}$ & & VIF & Path coefficient & $95 \% \mathrm{~B}$ & \\
\hline Airline service direct experience (ASDE) & AS & 0.181 & 25.516 & {$[0.168$} & 195] & 2.067 & 0.683 & {$[0.640$} & 718] \\
\hline & CS & 0.381 & 32.351 & {$[0.359$} & 405] & 2.333 & & & \\
\hline & ES & 0.325 & 29.700 & {$[0.305$} & 348] & 2.111 & & & \\
\hline & $\mathrm{OP}$ & 0.173 & 20.026 & {$[0.156$} & 190] & 1.564 & & & \\
\hline & PD & 0.164 & 25.169 & {$[0.151$} & 176] & 1.599 & & & \\
\hline
\end{tabular}

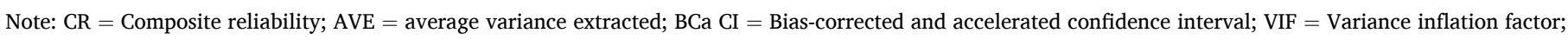
Convergent validity of second-order formative construct was examined using single global item. 
Table 5

Discriminant validity based on Heterotrait-Monotrait (HTMT) criterion.

\begin{tabular}{|c|c|c|c|c|c|c|c|c|c|c|}
\hline First-order constructs & 1 & 2 & 3 & 4 & 5 & 6 & 7 & 8 & 9 & 10 \\
\hline \multicolumn{11}{|l|}{ 1. AS } \\
\hline 2. BA & 0.538 & & & & & & & & & \\
\hline 3. BC & 0.712 & 0.597 & & & & & & & & \\
\hline 4. $\mathrm{BM}$ & 0.642 & 0.695 & 0.789 & & & & & & & \\
\hline 5. CS & 0.748 & 0.602 & 0.824 & 0.731 & & & & & & \\
\hline 6. ES & 0.679 & 0.513 & 0.746 & 0.681 & 0.722 & & & & & \\
\hline 7. OP & 0.603 & 0.443 & 0.619 & 0.502 & 0.611 & 0.557 & & & & \\
\hline 8. PD & 0.607 & 0.530 & 0.631 & 0.636 & 0.594 & 0.631 & 0.436 & & & \\
\hline 9. PV & 0.677 & 0.657 & 0.838 & 0.838 & 0.786 & 0.707 & 0.571 & 0.615 & & \\
\hline 10. SBE & 0.600 & 0.644 & 0.752 & 0.812 & 0.699 & 0.647 & 0.507 & 0.608 & 0.850 & \\
\hline
\end{tabular}

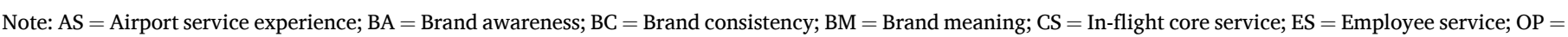
Interaction with other passengers; $\mathrm{PD}=$ Purchase decision experience; $\mathrm{PV}=$ Perceived value; $\mathrm{SBE}=\mathrm{Service}$ brand equity.

model. Using 5000 bootstrapping, the results in Table 6 show that ASDE was found to be a strong significant predictor of $\mathrm{BC}(\beta=0.810, t=$ $52.135, p<0.001)$. Moreover, the 95\% BCa CI: [0.782; 0.834] of this path relationship did not contain any zero between the lower and upper limits of the confidence interval, indicating a significant positive effect. Thus, H1 was supported. Similarly, the path relationships of ASDE $\rightarrow$ BA $(\beta=0.437, t=7.170, p<0.001)$, ASDE $\rightarrow \mathrm{BM}(\beta=0.409, t=8.290$, $p<0.001)$, ASDE $\rightarrow$ PV $(\beta=0.430, t=9.912, p<0.001)$ were statistically significant. Hence, H2, H3, and H4 were supported, showing positive influence of ASDE on BA, BM, and PV. Based on the size of path coefficient between direct service experience and brand equity components, it can be concluded that ASDE has a stronger positive influence on $\mathrm{BC}$, followed by BA, PV, and BM. The relationships between BC and other brand equity components (i.e., BA, BM, and PV) were also examined. The results indicate that the highest effect of 0.419 ( $\beta=$ $0.419, \mathrm{t}=8.988, p<0.001$ ) was estimated between BC and PV, followed by $0.379(\beta=0.379, t=7.799, \mathrm{p}<0.001)$ of $\mathrm{BC} \rightarrow \mathrm{BM}$; and 0.190 $(\beta=0.190, t=3.190, p<0.001)$ of $\mathrm{BC} \rightarrow \mathrm{BA}$, which were all significant at $95 \% \mathrm{BCa}$ CI. Thus, $\mathrm{H} 5, \mathrm{H} 6$, and $\mathrm{H} 7$ were supported, suggesting that $\mathrm{BC}$ has a significant positive influence on PV, BM, and BA, respectively. Finally, the relationships between brand equity constructs (i.e., BA, BM, and PV) and SBE were also positive and significant. Among the predictors, PV was the strongest $(\beta=0.497, \mathrm{t}=11.375, p<0.001)$, followed by $\mathrm{BM}(\beta=0.288, t=6.108, p<0.001)$; and $\mathrm{BA}(\beta=0.113, t=$ $3.580, p<0.001)$. Hence, H8, H9, and H10 were supported.

4.2.2. In-sample and out-of-sample prediction accuracy of CBSBE model In-sample prediction indicates the level of prediction accuracy within the sample group of respondents, while out-of-sample prediction elucidates the ability of a theoretical model to be applicable in a study population, regarded as predictive validity (Hair et al., 2019a). Starting from the key endogenous variable of the CBSBE model (see Fig. 2), SBE explains $66.5 \%$ variance $\left(R^{2}=0.665\right)$ by three predictors, namely BA, $\mathrm{BM}$, and $\mathrm{PV}$, which is regarded as a substantial level of in-sample predictive strength (Chin, 1998). Similarly, a variance of $65.2 \%$ in PV $\left(R^{2}=\right.$ $0.652), 56.1 \%$ in BM $\left(R^{2}=0.561\right), 36.1 \%$ in BA $\left(R^{2}=0.361\right)$, and $65.6 \%$ in BC $\left(R^{2}=0.656\right)$ indicate substantial, moderate, and substantial predictive accuracy, respectively (Chin, 1998). When assessing the predictive strength of each antecedent as compared to others in a model, effect size $\left(f^{2}\right)$ offers an estimation of predictive ability, represented by small (0.02), medium (0.15), and large (0.35) (Chin, 2010; Cohen, 1988). The results in Table 6 demonstrate that an effect size of 0.299 in $\mathrm{PV} \rightarrow \mathrm{SBE}$, deemed as moderate or close to high relative effect on SBE, while $\mathrm{BM} \rightarrow \mathrm{SBE}\left(f^{2}=0.097\right)$ and $\mathrm{BA} \rightarrow \mathrm{SBE}\left(f^{2}=0.022\right)$ have small effect sizes on SBE. This signifies that $\mathrm{PV}$ has a stronger relative effect, followed by BM and BA in explaining the variance in SBE. Likewise, $\mathrm{ASDE}$ is a stronger predictor than $\mathrm{BC}$ in explaining the variance in BA, $\mathrm{BM}$, and PV (see Table 6). Next, using the blindfolding procedure, the value of cross-validated redundancy $\left(Q^{2}\right)$ was 0.22 for BA. Whereas, the $Q^{2}$ value of all other endogenous variables (i.e., BM, PV, BC, and SBE) ranges from 0.39 to 0.47 , supporting small to large in-sample predictive accuracy of the CBSBE model (Hair et al., 2020; Hair et al., 2019a). Table 6 presents the results of hypotheses testing and in-sample prediction power of the CBSBE model.

Finally, the model's out-of-sample predictive accuracy was examined using PLSpredict in Shmueli et al. (2019) by setting up the algorithm as a

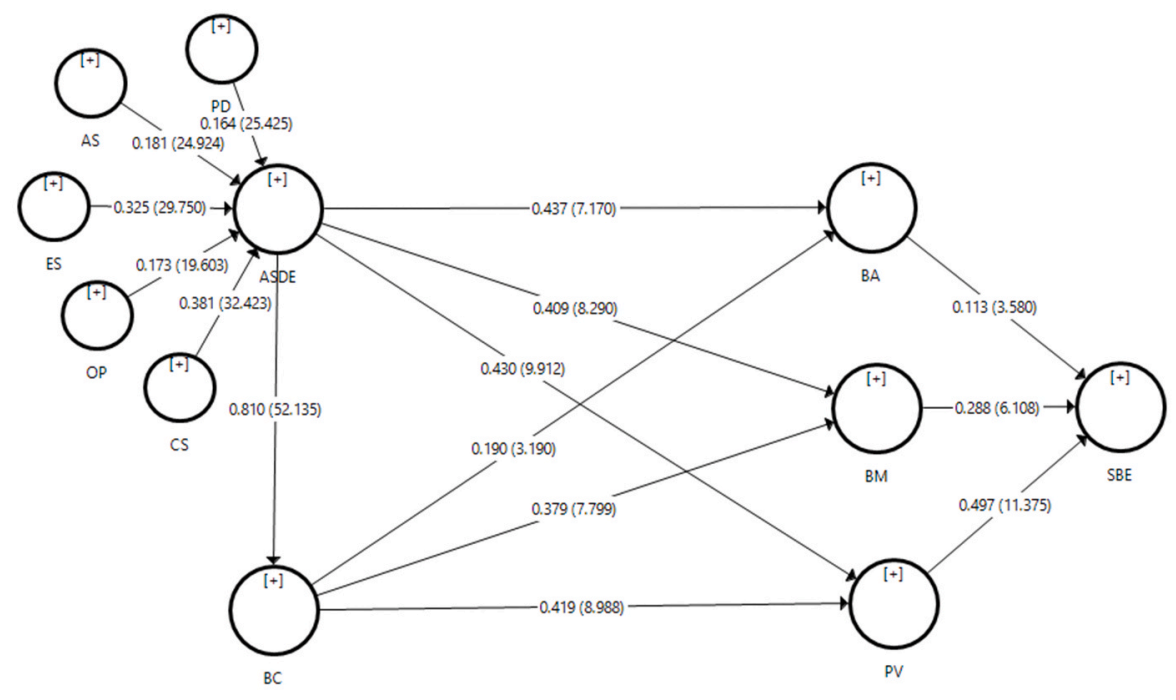

Fig. 2. PLS-SEM assessment of CBSBE model. 
Table 6

Structural model assessment.

\begin{tabular}{|c|c|c|c|c|c|c|c|c|}
\hline Hypotheses & Paths & Std. beta $(\boldsymbol{\beta})$ & $95 \%$ BCa CI & Supported & VIF & $R^{2}$ & $f^{2}$ & $Q^{2}$ \\
\hline $\mathrm{H} 1$ & $\mathrm{ASDE} \rightarrow \mathrm{BC}$ & $* * * 0.810$ & {$[0.782 ; 0.834]$} & Yes & 1.000 & 0.656 & 1.907 & 0.433 \\
\hline $\mathrm{H} 2$ & $\mathrm{ASDE} \rightarrow \mathrm{BA}$ & $* * * 0.437$ & {$[0.338 ; 0.536]$} & Yes & 2.907 & 0.361 & 0.103 & 0.218 \\
\hline H3 & $\mathrm{ASDE} \rightarrow \mathrm{BM}$ & $* * * 0.409$ & {$[0.327 ; 0.491]$} & Yes & 2.907 & 0.561 & 0.131 & 0.387 \\
\hline $\mathrm{H} 4$ & $\mathrm{ASDE} \rightarrow \mathrm{PV}$ & $* * * 0.430$ & {$[0.358 ; 0.502]$} & Yes & 2.907 & 0.652 & 0.183 & 0.420 \\
\hline H5 & $\mathrm{BC} \rightarrow \mathrm{BA}$ & $* * * 0.190$ & {$[0.091 ; 0.286]$} & Yes & 2.907 & & 0.020 & \\
\hline H6 & $\mathrm{BC} \rightarrow \mathrm{BM}$ & $* * * 0.379$ & {$[0.298 ; 0.456]$} & Yes & 2.907 & & 0.112 & \\
\hline H7 & $\mathrm{BC} \rightarrow \mathrm{PV}$ & $* * * 0.419$ & {$[0.341 ; 0.493]$} & Yes & 2.907 & & 0.173 & \\
\hline H8 & $\mathrm{BA} \rightarrow \mathrm{SBE}$ & $* * * 0.113$ & {$[0.060 ; 0.163]$} & Yes & 1.737 & 0.665 & 0.022 & 0.470 \\
\hline H9 & $\mathrm{BM} \rightarrow \mathrm{SBE}$ & $* * * 0.288$ & {$[0.212 ; 0.367]$} & Yes & 2.560 & & 0.097 & \\
\hline $\mathrm{H} 10$ & $\mathrm{PV} \rightarrow \mathrm{SBE}$ & $* * * 0.497$ & {$[0.421 ; 0.564]$} & Yes & 2.468 & & 0.299 & \\
\hline
\end{tabular}

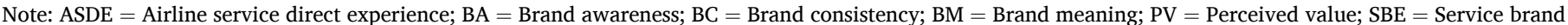
equity. Critical t value $* * 3.090(p<0.001)$ [One-tailed]; BCa CI $=$ Bias-corrected and accelerated confidence interval; VIF $=$ Variance inflation factor.

cross-validation $k$-fold $=10$. Given our focus is on the key endogenous variable, i.e., SBE, the $Q^{2}$ predict values were found to be above zero $\left(Q^{2}\right.$ predict $\left.>0\right)$ [see Table 7]. Besides, other endogenous constructs' $\mathrm{Q}^{2}$ predict were also above zero [e.g., BC (0.634), PV (0.557), BM (0.455), and BA (0.220)], indicating that PLS model's prediction error is below the prediction error of simple mean value (Hair et al., 2019a). Next, to assess the indicator level prediction accuracy, the root mean squared error (RMSE) is highly recommended as a naïve benchmark to compare the estimation error between analysis (PLS-SEM) and the holdout (LM) sample (Hair et al., 2020; Shmueli et al., 2019). The results in Table 7 demonstrate that the RMSE of PLS-SEM yields lower than LM sample. Furthermore, the $Q_{\text {predict }}^{2}$ of SBE's indicators are higher in PLS-SEM compared to LM sample, yielding a strong support for high out-of-sample predictive power of our CBSBE model (Hair et al., 2020; Shmueli et al., 2019).

\subsection{Robustness assessment of CBSBE model}

Guided by the recent advancement in PLS-SEM techniques (Hair et al., 2020; Hair et al., 2019b), we employed three statistical tests to check the robustness of our model: 1) nonlinearity effect, 2) assessment of unobserved heterogeneity, and 3) endogeneity test.

To test the presence and significance of nonlinearity (Svensson et al., 2018), first, the quadratic effect terms for all endogenous constructs were created using 5000 bootstrapping with no sign changes. None of the nonlinear effects show significance. Second, the Ramsey's RESET test (Ramsey, 1969) was deployed to further investigate the significance of the nonlinear effect model. Using the latent variable score derived from PLS-SEM basic algorithm, the Ramsey's RESET test was executed via SPSS (Sarstedt and Mooi, 2019). The results showed that none of the regression models of $\mathrm{BC}, \mathrm{BA}, \mathrm{BM}, \mathrm{PV}$, and SBE is significant in regard to nonlinear effect. Although the nonlinear effect of ASDE on PV is marginally insignificant, the regression model of ASDE and BC on PV was found to be strongly insignificant [i.e., $F(2,647)=0.527 ; p=$ 0.591 ], substantiating the evidence of linearity effects of our CBSBE model (see Appendix A in Supplementary data).

Secondly, the unobserved heterogeneity was examined to check whether any potential variances were presumed in the overall dataset (Hair et al., 2019a). The finite mixture PLS (FIMIX-PLS) (Hair et al. (2018) procedure was executed which prompted a four-segment solution based on minimum sample size requirements. The results offer a sustainable solution when either "AIC3 and CAIC" or "AIC4 and BIC" indicate similar number of segments; this is also the case when the corresponding entropy (EN) value is evidently higher than the cut-off value of 0.5 (Sarstedt et al., 2019). The results in the current study indicate that neither "AIC3 and CAIC" nor "AIC4 and BIC" estimate a consistent number of segments in the model. Besides, none of the corresponding values of EN surpasses the minimum value of 0.50 , indicating the absence of unobserved heterogeneity in the model (see Appendix B in Supplementary data).

Finally, the test of endogeneity provides a framework for validating our CBSBE model (Hair et al., 2019b; Svensson et al., 2018). Guided by the procedures and R code provided in Hult et al. (2018), the Park and Gupta's (2012) Gaussian copula analysis was carried out using latent variable scores. None of the Gaussian copula models (whether single or multiple variables) included as endogenous constructs were found to be significant, supporting the robustness of our CBSBE model regarding the absence of endogeneity (see Appendix C in Supplementary data).

Overall, the results provide validation that our proposed model has strong predictive power in explaining new observations beyond the current group of respondents. Besides, the application of advanced PLSSEM analyses affirms that CBSBE model for explaining the theoretical aspects of airline service brand equity creation is highly robust.

\section{Discussions and conclusion}

Given the complexities of building a strong service brand, previous studies have ignored the importance of conceptualizing and validating a more adaptable service brand equity model. We adopt the theoretical conceptualization of service branding theory (i.e., CBSBE) in Sarker et al. (2019) and operationalize it in the airline service setting. Despite Sarker et al.'s effort in proposing a service branding model, the operationalization of each construct is required to examine the model's parsimony and validity. This research attempts to fill these gaps by

Table 7

PLSpredict assessment of key construct.

\begin{tabular}{|c|c|c|c|c|c|c|c|}
\hline \multicolumn{2}{|c|}{ Key endogenous construct } & \multicolumn{2}{|c|}{ PLS-SEM } & \multicolumn{2}{|c|}{ LM } & \multicolumn{2}{|c|}{ PLS-SEM - LM (Difference) } \\
\hline SBE & Indicators & RMSE & $Q_{\text {predict }}^{2}$ & RMSE & $Q^{2}$ predict & RMSE & $Q_{\text {predict }}^{2}$ \\
\hline$\left(Q^{2}\right.$ predict $\left.=0.430\right)$ & SBE1 & 0.851 & 0.415 & 0.868 & 0.391 & -0.017 & 0.024 \\
\hline & SBE2 & 0.911 & 0.324 & 0.931 & 0.295 & -0.020 & 0.029 \\
\hline & SBE3 & 0.896 & 0.340 & 0.909 & 0.320 & -0.013 & 0.020 \\
\hline & SBE4 & 0.912 & 0.362 & 0.935 & 0.330 & -0.023 & 0.032 \\
\hline & SBE5 & 0.942 & 0.397 & 0.969 & 0.362 & -0.027 & 0.035 \\
\hline
\end{tabular}

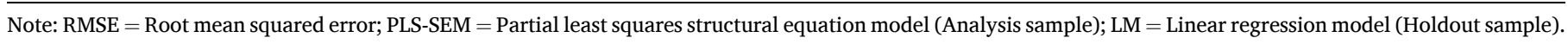


testing and validating the CBSBE model in an airline context. Adopting the PLS-SEM methods, our empirical results demonstrate that perceived value is the key determinant for building service brand equity for airlines, followed by brand meaning and brand awareness. Airline service direct experience and brand consistency have strong positive impact on creating perceived value and brand meaning. Brand consistency also has strong and positive association with airline service direct experience. The supplementary analyses further validate that the proposed CBSBE model is robust, providing methodological contribution (Svensson et al., 2018).

\subsection{Theoretical implications}

This research contributes to the service branding theory by extending Berry's $(2000,2016)$ theoretical model with the addition of brand consistency $(B C)$ and perceived value $(P V)$. A more comprehensive role for direct service experience was also conceptualized. As heterogeneity and intangibility are the key generic characteristics of intangible-dominant services (Lovelock and Gummesson, 2004), maintaining consistency across the various service encounters is a challenging task for service organizations. Scholars also advocate that BC in each service encounter ensures a brand's capability to meet consumers' expectations (Erdem \& Swait, 1998, 2016; Keller, 1993). PV, on the other hand, has been acknowledged as the nerve center of service brand (Helkkula et al., 2012; Merz et al., 2009), and has been linked to positive customer response (Kumar and Reinartz, 2016). Despite BC and PV having crucial significance in previous marketing literature, little evidence was found to integrate these two variables into the existing service branding models. The inclusion of $\mathrm{BC}$ and $\mathrm{PV}$ in our theoretical model deepens the foundation of service branding theory. For the service brands, consumer experience with services is the nucleus of creating value (Helkkula et al., 2012; Olsson et al., 2012; Vargo and Lusch, 2017). However, the role of direct service experience in building service brand equity (SBE) has been marginally addressed in past literature. Precisely, Berry (2000, 2016) conceptually explain the role of direct service experience only in creating brand meaning (BM). Our study argues that direct service experience strengthens all the brand equity components (i.e., brand consistency, brand awareness, brand meaning, and perceived value). Hence, we believe that our theoretical framework of branding services, or CBSBE, is more comprehensive than previous models by incorporating the complex role of direct service experience, $\mathrm{BC}$, and $\mathrm{PV}$.

To validate the CBSBE model in the context of airlines, we examined a total of ten hypotheses. Our findings affirm that all the consumer touchpoints (i.e., purchase decision experience, service process, employee service, servicescapes, etc.) must be designed in a way that a standard level of service experience could be maintained throughout the consumption journey. Like other services, passengers derive their impression about the airline brand through congruency in service experience, as each touchpoint conveys a particular message/value to the consumer (Prentice and Correia Loureiro, 2017). On the contrary, an inconsistent experience across the service consumption journey suggests a mixed impression about the brand, which diminishes the brand equity of the service. For instance, if a passenger encounters a poor level of in-flight core service and employee service, but a pleasant experience during purchase decision and airport service, the passenger will perceive discrepancy in assessing the brand equity of that airline. Due to the failure in conveying a consistent level of service through the direct experience touchpoints, airline service providers might encounter difficulties in creating a strong brand.

An enjoyable service experience (i.e., ASDE) is often deeply-rooted in consumer's long-term memory and reinforces them to retain and recall the experience (Lemon and Verhoef, 2016). Thus, pleasant experiences at check-in, luggage handling, inside the aircraft, etc., (i.e., ASDE components) would trigger the passenger to remember and recall the name, logo, and service nature of the airline quickly and vividly. However, a small effect size of the relationship between BC and BA signifies that, although the standardized effect of creating brand awareness through brand consistency is relatively weak, the practical importance cannot be ignored.

A significant positive effect between ASDE and BM suggests that an enjoyable service experience will create a favorable descriptive identity/ meaning (BM) for airlines. The association between direct service experience (i.e., ASDE) and BM is strong; in this way, every touchpoint delivers benefits to consumers through which overall image/meaning of the service is implicitly assessed (Lovelock and Wirtz, 2011; Zeithaml, 1981). Besides, the level of consistency across the consumer touchpoints (i.e., BC) is also vital as we found a strong effect on BM. Erdem and Swait (1998, 2016) also opined that BC signals the brand's credibility and clarity (i.e., trustworthiness, reliability etc.), which are regarded as favorable associations of a brand. In airline service, when passengers encounter various touchpoints, each touchpoint experience should be harmonious and congruent with the experience derived from the last encounter. This consistency brings a subsequent effect in developing a unique favorable image of the airline brand and ensures the credibility of service performance (i.e., BM).

The two strongest positive significant effects of ASDE $\rightarrow \mathrm{PV}$ and $\mathrm{BC} \rightarrow$ $\mathrm{PV}$ validate the theoretical notion of creating value of the service brand. Mitchell et al. (2016) argue that consumers realize value through various interactions with multiple actors and service encounters, instead of a dyadic co-creation mechanism. Over the service consumption journey, consumers encounter a series of direct touchpoints through which various types of benefits i.e., functional, time, efforts, emotional/psychological, are experienced at the expense of monetary, time, physiological and psychological efforts. A positive trade-off value between benefits and sacrifices manifests a higher PV (Kumar and Reinartz, 2016; Zeithaml, 1988). This study argues that each direct touchpoint delivers value, which either increases or diminishes depending on passengers' evaluation of ASDE components. Thus, an enjoyable experience on each service encounter helps to strengthen the PV of service brands, while a poor service experience degrades the value. Furthermore, consistency of service experience across the direct touchpoints reduces the perceived risks of consumers and yields confidence in purchase decision making (Erdem \& Swait, 1998, 2016). Therefore, the ability to deliver consistent services at the promised level throughout the consumption journey would be advantageous to airline brands, which can be realized through a careful delivery of ASDE touchpoints.

SBE is conceived as the consumer differential response when making a purchase decision. Among the three antecedents of SBE, i.e., BA, BM, and PV, PV has the largest positive significant effect, followed by BM and BA. Creating a positive service brand equity is instrumental for building a strong service brand (Berry, 2000, 2016). According to Berry, for experienced consumers, brand meaning as opposed to brand awareness is more influential in creating positive service brand equity; whereas, brand awareness derived from the indirect experience touchpoints are influential in creating service brand equity for inexperienced consumers. Although this analogy in Berry (2000) aligns with the SDL view (Brodie et al., 2006), our findings conflict with Berry's concerning the expressive role of PV in creating SBE for airlines. We argue that PV is the central route compared to $\mathrm{BM}$ and $\mathrm{BA}$ in creating service brand equity, whereas BA has the least effect on SBE. In services marketing, value is viewed as a central aspect of exchange between beneficiaries and providers (Vargo and Lusch, 2017) and influences the consumer response positively (Bajs, 2015; Lam et al., 2010; Sweeney and Soutar, 2001). Likewise, a favorable meaning of a service brand (i.e., BM) performs a crucial role in creating positive brand equity of services (Berry, 2000; García et al., 2012; So and King, 2010). Notably, in an invisible purchase (i.e., intangible-dominant brands), a sense of credibility, reliability, trustworthiness, strong personality, pleasant feelings about a brand etc., influence consumers' purchase decision (Belboula and Ackermann, 2019; Berry and Seltman, 2007). Whereas, high brand awareness alone is not sufficient to induce positive behavioral response from consumers with prior service consumption experience. Therefore, we argue that 
maximizing value and creating favorable meaning by providing pleasant service experiences as well as nurturing consistency across the various direct touchpoints are the keys for building a strong service equity.

\subsection{Managerial implications}

The findings of this study are highly relevant for services marketing practitioners, given the inclusion of the diverse roles of direct service experience in creating service brand equity. The empirical results reveal that passengers' incremental positive response to a previously experienced airline compared to other airline brands (i.e., SBE) strongly depends on the materialization of perceived value and brand meaning. Thus, value maximization and ways of achieving favorable service brand meaning should be prioritized by managers. As value emerges and materializes through customer experience (Kumar and Reinartz, 2016; Vargo and Lusch, 2017), delivering enjoyable, pleasant, and consistent service would elevate the perceived value of services. A higher level of brand value materializes when consumer-derived experiences (benefits) are higher (i.e., enjoyable, pleasant) compared to the investment of time, psychological and physical effort, and money (sacrifices). Holmlund et al. (2020) elucidate that managing customer experience efficiently and effectively is linked to organization's strength. Airline managers must understand the diverse sacrifices made by consumers in delivering the desired level of service experiences. In this regard, servicescapes (i.e., in-flight core service) and employee service must be prioritized along with the service process (i.e., airport service experience), other audience in the servicescapes (i.e., other passengers), and purchase decision experience in delivering services. More importantly, health and safety measures must be accorded the highest priority across all direct service touchpoints to combat infectious diseases like COVID-19, SARS, MERS etc. Among these measures, sanitizing aircrafts and other contact points, setting up air purifier inside aircrafts, providing hygiene materials and gears, and educating passengers about self-hygiene would mitigate their fears about hygiene issues. Besides, reliability, credibility, and pleasant experience, as well as health and safety services constitute the baseline for creating a positive brand image of service organizations, while a competitive assessment is necessary to develop its distinctiveness. For instance, innovative service provisions (i.e., service automation, use of artificial intelligence), hospitable service, meals, waiting lounge service, airport service, flight booking service, brand name, color, theme, etc., all convey the meaning of an airline brand. Thus, strategy makers of airline companies must decide which associations/meaning/image they want to establish in the passengers' mind, ensuring that each experience point is harmonized to create a unique BM.

The direct service experience components must be congruent across the encounter concerning the level of service standards and promises made before delivering the actual service. Marketers propose value to the consumer by making promises which are planned to be delivered through products and services (Kotler and Armstrong, 2017). Indeed, value is communicated and delivered through each encounter until the products/services are consumed. A high level of brand consistency is perceived when consumers experience congruency between promises and experiences in each encounter. Therefore, service marketing managers must cultivate each touchpoint by carefully designing each direct service experience component (i.e., servicescapes, employee service, the service process, purchase decision experience, and other consumers in servicescapes). For example, if an airline wishes to deliver a warm and reliable service, the nature of such service must reflect in each encounter of the service consumption experience journey. Marketing communications must be harmonized with the level of service provided to the passenger. Also, the value propositions of an airline brand should not be exaggerated. Thus, a suitable strategy would be: "what we promise, we deliver."

For experienced consumers, since perceived value and brand meaning feature prominently in decision making, brand awareness does little to elevate positive differential response. However, the role of brand awareness in creating positive service brand equity cannot be neglected; because high awareness among the experienced consumers would help recall previous experience and facilitate recognizing the service brand more strongly over others. Hence, by delivering exciting services that could create lasting impressions, satisfied consumers may share the name of the service brand among their network of friends and relatives. Moreover, brand name, logo, color, tagline, unique image, etc., of the service company must be displayed frequently and repeatedly during the ASDE encounters so that passengers are exposed in every touchpoint, which would expedite the storing of brand-related information in their long-term memory.

\subsection{Limitations and future research}

While this study validates an alternative service branding theory called the CBSBE model, some limitations remain. First, as Berry et al. (2006) noted that consumers' assessment of services depends on the various clues engrained in service performance rather than objects, we propose a service branding theory based on direct service experience only. Indirect service experience components such as advertisement, publicity, word-of-mouth etc., are meant to deliver various types of information related to brands for promoting, persuading, and informing the target audience (Belch and Belch, 2018). Thus, it is assumed that consumers assess the difference between products and services based on the experience encountered with direct service components instead of indirect encounters. Hence, we develop the CBSBE model by focusing on direct service experience elements and validate it using an intangible-dominant service, i.e., airline. However, the role of indirect service experience cannot be completely neglected. Future studies may incorporate the indirect service experience and examine its effect on brand equity components in developing an integrated service branding model.

Second, as we operationalized the CBSBE model using only one service industry, a careful attention is needed while investigating service brand equity in other service category. We have calibrated direct service experience components using the five components specific to airline service. The direct service experience components must be tailored to a specific service categorie when investigating service brand equity in other settings. Hence, we suggest future research in other service sector such as healthcare, education, lodging, consulting, and even sharing economy services (such as Airbnb, Uber, Lyft etc.), which are all intangible-dominant (Shostack, 1982) and high in experience and credence qualities (Zeithaml, 1981).

Third, although the inclusion of indirect service experience may provide a broad understanding of service branding in future research, caution must be exercised when extending the service branding theory to both experienced and inexperienced consumers. The data utilized in this study were collected from experienced airline passengers, thus applying these findings to consumers with no previous service consumption experience may be less helpful.

Finally, the CBSBE model was validated in an Asian country, where the majority of the survey respondents were Asian (43.60\%) and European $(31 \%)$. Therefore, future research on airline service branding could be conducted in other locations such as Europe, America, and Australia, and the quota sampling technique can be executed to include a proportional number of consumers of different nationalities.

\section{Funding}

The authors received no financial support for the research, authorship, and/or publication of this article.

\section{Declaration of conflicting interests}

The authors declared no potential conflicts of interest concerning the 
research, authorship, and/or publication of this article.

\section{Supplementary data}

Supplementary data to this article can be found online at https://doi. org/10.1016/j.jretconser.2020.102354.

\section{References}

Aaker, D.A., 1991. Managing Brand Equity: Capitalizing on the Value of a Brand Name. The Free Press, New York.

Aaker, D.A., 1996. Measuring brand equity across products and markets. Calif. Manag. Rev. 38 (3).

Adapa, S., Roy, S.K., 2017. Case study 6: Malaysian airlines versus AirAsia: customer satisfaction, service quality and service branding. In: Roy, S.K., Mutum, D.S., Nguyen, B. (Eds.), Services Marketing Cases in Emerging Markets: an Asian Perspective. Springer International Publishing, Cham, pp. 67-75.

Ali, F., Amin, M., Cobanoglu, C., 2016. An integrated model of service experience, emotions, satisfaction, and price acceptance: an empirical analysis in the Chinese hospitality industry. J. Hospit. Market. Manag. 25 (4), 449-475.

Armstrong, J.S., Overton, T.S., 1977. Estimating nonresponse bias in mail surveys. J. Market. Res. 14 (3), 396-402.

Baalbaki, S., Guzmán, F., 2016. A consumer-perceived consumer-based brand equity scale. J. Brand Manag. 23 (3), 229-251. https://doi.org/10.1057/bm.2016.11.

Bajs, I.P., 2015. Tourist perceived value, relationship to satisfaction, and behavioral intentions. J. Trav. Res. 54 (1), 122-134.

Bal, P.M., Kooij, D.T.A.M., De Jong, S.B., 2013. How do developmental and accommodative HRM enhance employee engagement and commitment? The role of psychological contract and SOC strategies. J. Manag. Stud. 50 (4), 545-572.

Batouei, A., Iranmanesh, M., Nikbin, D., Hyun, S.S., 2019. Flight anxiety: investigating the role of airline service quality and flight crew's competence. Asia Pac. J. Tourism Res. 24 (7), 710-724.

Belboula, I., Ackermann, C.-L., 2019. Consumer response to service brand physical elements: using a semantic priming task to explore implicit understanding of service brand meaning. J. Retailing Consum. Serv., 102019

Belch, G.E., Belch, M.A., 2018. In: Advertising and Promotion: an Integrated Marketing Communications Perspective, eleventh ed. McGraw-Hill Education, New York.

Berry, L.L., 2000. Cultivating service brand equity. J. Acad. Market. Sci. 28 (1), 128-137.

Berry, L.L., 2016. Revisiting" big ideas in services marketing" 30 years later. J. Serv. Market. 30 (1), 3-6.

Berry, L.L., Seltman, K.D., 2007. Building a strong services brand: lessons from mayo clinic. Bus. Horiz. 50 (3), 199-209.

Berry, L.L., Wall, E.A., Carbone, L.P., 2006. Service clues and customer assessment of the service experience: lessons from marketing. Acad. Manag. Perspect. 20 (2), 43-57.

Beverland, M.B., Wilner, S.J., Micheli, P., 2015. Reconciling the tension between consistency and relevance: design thinking as a mechanism for brand ambidexterity. J. Acad. Market. Sci. 43 (5), 589-609.

Bianchi, C., Pike, S., Lings, I., 2014. Investigating attitudes towards three South American destinations in an emerging long haul market using a model of consumerbased brand equity (CBBE). Tourism Manag. 42, 215-223.

Bitner, M.J., 1992. Servicescapes: the impact of physical surroundings on customers and employees. J. Market. 56 (2), 57-71.

Brocato, E.D., Voorhees, C.M., Baker, J., 2012. Understanding the influence of cues from other customers in the service experience: a scale development and validation. J. Retailing 88 (3), 384-398.

Brodie, R.J., 2009. From goods to service branding: an integrative perspective. Market. Theor. 9 (1), 107-111.

Brodie, R.J., de Chernatony, L., 2009. Towards new conceptualizations of branding: theories of the middle range. Market. Theor. 9 (1), 95-100.

Brodie, R.J., Glynn, M.S., Little, V., 2006. The service brand and the service-dominant logic: missing fundamental premise or the need for stronger theory? Market. Theor 6 (3), 363-379.

Brodie, R.J., Whittome, J.R.M., Brush, G.J., 2009. Investigating the service brand: a customer value perspective. J. Bus. Res. 62 (3), 345-355.

Buil, I., de Chernatony, L., Martínez, E., 2013b. Examining the role of advertising and sales promotions in brand equity creation. J. Bus. Res. 66 (1), 115-122.

Buil, I., Martínez, E., de Chernatony, L., 2013a. The influence of brand equity on consumer responses. J. Consum. Market. 30 (1), 62-74.

Byrne, B.M., 2016. In: Structural Equation Modeling with AMOS: Basic Concepts, Applications, and Programming, third ed. Routledge, New York.

CAPA, 2020. COVID-19. By the end of May, most world airlines will be bankrupt. Retrieved March 19, 2020. https://centreforaviation.com/analysis/reports/co vid-19-by-the-end-of-may-most-world-airlines-will-be-bankrupt-517512.

Chatzipanagiotou, K., Veloutsou, C., Christodoulides, G., 2016. Decoding the complexity of the consumer-based brand equity process. J. Bus. Res. 69 (11), 5479-5486.

Chen, C.-F., Tseng, W.-S., 2010. Exploring customer-based airline brand equity: evidence from Taiwan. Transport. J. 49 (1), 24-34.

Chin, W.W., 1998. The partial least squares approach to structural equation modeling. In: Marcoulides, G.A. (Ed.), Modern Methods for Business Research. Lawrence Erlbaum, Hillsdale, New Jersey, pp. 295-336.

Chin, W.W., 2010. How to write up and report PLS analyses. In: Esposito Vinzi, V. Chin, W.W., Henseler, J., Wang, H. (Eds.), Handbook of Partial Least Squares:
Concepts, Methods and Applications. Springer Berlin Heidelberg, Berlin, Heidelberg, pp. 655-690.

Chin, W.W., Thatcher, J.B., Wright, R.T., Steel, D., 2013. Controlling for common method variance in PLS analysis: the measured latent marker variable approach. In: Abdi, H., Chin, W.W., Vinzi, V.E., Russolillo, G., Trinchera, L. (Eds.), New Perspectives in Partial Least Squares and Related Methods, vol. 56. Springer, New York, pp. 231-239.

Çifci, S., Ekinci, Y., Whyatt, G., Japutra, A., Molinillo, S., Siala, H., 2016. A cross validation of Consumer-Based Brand Equity models: driving customer equity in retail brands. J. Bus. Res. 69 (9), 3740-3747.

Cohen, J., 1988. In: Statistical Power Analysis for the Behavioral Sciences, second ed. Psychology Press, New York.

Coltman, T., Devinney, T.M., Midgley, D.F., Venaik, S., 2008. Formative versus reflective measurement models: two applications of formative measurement. J. Bus. Res. 61 (12), 1250-1262.

Cowley, E., 2007. How enjoyable was it? Remembering an affective reaction to a previous consumption experience. J. Consum. Res. 34 (4), 494-505.

Dagger, T.S., Sweeney, J.C., Johnson, L.W., 2007. A hierarchical model of health service quality:scale development and investigation of an integrated model. J. Serv. Res. 10 (2), 123-142.

de Chernatony, L., Cottam, S., 2006. Internal brand factors driving successful financial services brands. Eur. J. Market. 40 (5/6), 611-633.

de Chernatony, L., McDonald, M., Wallace, E., 2011. In: Creating Powerful Brands, fourth ed. Butterworth-Heinemann.

Delgado-Ballester, E., Navarro, A., Sicilia, M., 2012. Revitalising brands through communication messages: the role of brand familiarity. Eur. J. Market. 46 (1/2), $31-51$.

Diamantopoulos, A., Siguaw, J.A., 2006. Formative versus reflective indicators in organizational measure development: a comparison and empirical illustration. Br. J. Manag. 17 (4), 263-282.

Erdem, T., Swait, J., 1998. Brand equity as a signaling phenomenon. J. Consum. Psychol. 7 (2), 131-157.

Erdem, T., Swait, J., 2016. The information-economics perspective on brand equity. Found. Trends® Microecon. 10 (1), 1-59.

Faul, F., Erdfelder, E., Buchner, A., Lang, A.-G., 2009. Statistical power analyses using $\mathrm{G}^{*}$ Power 3.1: tests for correlation and regression analyses. Behav. Res. Methods 41 (4), 1149-1160.

Franke, G., Sarstedt, M., 2019. Heuristics versus statistics in discriminant validity testing: a comparison of four procedures. Internet Res. 29 (3), 430-447.

Fuller, C.M., Simmering, M.J., Atinc, G., Atinc, Y., Babin, B.J., 2016. Common methods variance detection in business research. J. Bus. Res. 69 (8), 3192-3198.

García, J.A., Gómez, M., Molina, A., 2012. A destination-branding model: an empirical analysis based on stakeholders. Tourism Manag. 33 (3), 646-661.

Gil, I., Berenguer, G., Cervera, A., 2008. The roles of service encounters, service value, and job satisfaction in achieving customer satisfaction in business relationships. Ind. Market. Manag. 37 (8), 921-939.

Grace, D., O'Cass, A., 2005. Service branding: consumer verdicts on service brands. J. Retailing Consum. Serv. 12 (2), 125-139.

Grönroos, C., 1984. A service quality model and its marketing implications. Eur. J. Market. 18 (4), 36-44.

Grönroos, C., Gummerus, J., 2014. The service revolution and its marketing implications: service logic vs service-dominant logic. Manag. Serv. Qual. 24 (3), 206-229.

Grove, S.J., Fisk, R.P., Dorsch, M.J., 1998. Assessing the theatrical components of the service encounter: a cluster Analysis examination. Serv. Ind. J. 18 (3), 116-134.

Hair, J.F., Howard, M.C., Nitzl, C., 2020. Assessing measurement model quality in PLSSEM using confirmatory composite analysis. J. Bus. Res. 109, 101-110.

Hair, J.F., Hult, G.T.M., Ringle, C.M., Sarstedt, M., 2017. In: A Primer on Partial Least Squares Structural Equation Modeling (PLS-SEM), second ed. Sage Publications, Los Angeles.

Hair, J.F., Risher, J.J., Sarstedt, M., Ringle, C.M., 2019a. When to use and how to report the results of PLS-SEM. Eur. Bus. Rev. 31 (1), 2-24.

Hair, J.F., Sarstedt, M., Ringle, C.M., 2019b. Rethinking some of the rethinking of partial least squares. Eur. J. Market. 53 (4), 566-584.

Hair, J.F., Sarstedt, M., Ringle, C.M., Gudergan, S.P., 2018. Advanced Issues in Partial Least Squares Structural Equation Modeling. SAGE, Thousand Oaks, CA.

Han, H., Hyun, S.S., Kim, W., 2014. In-flight service performance and passenger loyalty: a cross-national (China/Korea) study of travelers using low-cost carriers. J. Trav. Tourism Market. 31 (5), 589-609.

Helkkula, A., Kelleher, C., Pihlström, M., 2012. Characterizing value as an experience. J. Serv. Res. 15 (1), 59-75.

Henseler, J., Ringle, C.M., Sarstedt, M., 2015. A new criterion for assessing discriminant validity in variance-based structural equation modeling. J. Acad. Market. Sci. 43 (1), 115-135.

Henseler, J., Ringle, C.M., Sarstedt, M., 2016. Testing measurement invariance of composites using partial least squares. Int. Market. Rev. 33 (3), 405-431.

Holmlund, M., Van Vaerenbergh, Y., Ciuchita, R., Ravald, A., Sarantopoulos, P., Ordenes, F.V., Zaki, M., 2020. Customer experience management in the age of big data analytics: a strategic framework. J. Bus. Res. (6 February, 2020).

Hult, G.T.M., Hair, J.F., Proksch, D., Sarstedt, M., Pinkwart, A., Ringle, C.M., 2018. Addressing endogeneity in international marketing applications of partial least squares structural equation modeling. J. Int. Market. 26 (3), 1-21.

Hult, G.T.M., Ketchen, D.J., Griffith, D.A., Finnegan, C.A., Gonzalez-Padron, T., Harmancioglu, N., Cavusgil, S.T., 2008. Data equivalence in cross-cultural international business research: assessment and guidelines. J. Int. Bus. Stud. 39 (6), 1027-1044. 
Hunt, S.D., Sparkman, R.D., Wilcox, J.B., 1982. The pretest in survey research: issues and preliminary findings. J. Market. Res. 19 (2), 269-273.

IATA, 2020. Economic performance of the airline industry. Retrieved January 13, 2020. https://www.iata.org/en/iata-repository/publications/economic-reports/airline-i ndustry-economic-performance-december-2019-report/.

Jacoby, J., 2002. Stimulus-organism-response reconsidered: an evolutionary step in modeling (consumer) behavior. J. Consum. Psychol. 12 (1), 51-57.

Jun, S.H., Vogt, C.A., MacKay, K.J., 2010. Online information search strategies: a focus on flights and accommodations. J. Trav. Tourism Market. 27 (6), 579-595.

Kapferer, J.N., 2008. The New Strategic Brand Management: Creating and Sustaining Brand Equity. Kogan Page, London.

Karpen, I.O., Bove, L.L., Lukas, B.A., Zyphur, M.J., 2015. Service-dominant orientation: measurement and impact on performance outcomes. J. Retailing 91 (1), 89-108.

Keller, K.L., 1993. Conceptualizing, measuring, and managing customer-based brand equity. J. Market. 1-22.

Keller, K.L., 2012. In: Strategic Brand Management: Building, Measuring, and Managing Brand Equity, fourth ed. Pearson, USA.

Keller, K.L., 2016. Reflections on customer-based brand equity: perspectives, progress, and priorities. AMS Review 6 (1), 1-16.

Khan, N.T., Jung, G., Kim, J., Kim, Y.B., 2019. Evolving competition between low-cost carriers and full-service carriers: the case of South Korea. J. Transport Geogr. 74 (January 2019), 1-9.

Kim, K., Kim, K.S., Kim, D.Y., Kim, J.H., Kang, S.H., 2008b. Brand equity in hospital marketing. J. Bus. Res. 61 (1), 75-82.

Kim, S., Kim, I., Hyun, S.S., 2016. First-class in-flight services and advertising effectiveness: antecedents of customer-centric innovativeness and brand loyalty in the United States (US) airline industry. J. Trav. Tourism Market. 33 (1), 118-140.

Kim, W.G., Jin-Sun, B., Kim, H.J., 2008. Multidimensional customer-based brand equity and its consequences in midpriced hotels. J. Hospit. Tourism Res. 32 (2), 235-254.

Koklic, M.K., Kukar-Kinney, M., Vegelj, S., 2017. An investigation of customer satisfaction with low-cost and full-service airline companies. J. Bus. Res. 80 (November 2017), 188-196.

Konecnik, M., Gartner, W.C., 2007. Customer-based brand equity for a destination. Ann. Tourism Res. 34 (2), 400-421.

Kotler, P., Armstrong, G., 2017. In: Principles of Marketing, 17 ed. Pearson, Upper Saddle River, N.J., USA.

Kotsi, F., Pike, S., Gottlieb, U., 2018. Consumer-based brand equity (CBBE) in the context of an international stopover destination: perceptions of Dubai in France and Australia. Tourism Manag. 69, 297-306.

Krystallis, A., Chrysochou, P., 2014. The effects of service brand dimensions on brand loyalty. J. Retailing Consum. Serv. 21 (2), 139-147.

Kumar, V., Reinartz, W., 2016. Creating enduring customer value. J. Market. 80 (6), $36-68$.

Lam, S.K., Ahearne, M., Hu, Y., Schillewaert, N., 2010. Resistance to brand switching when a radically new brand is introduced: a social identity theory perspective. J. Market. 74 (6), 128-146.

Lassar, W., Mittal, B., Sharma, A., 1995. Measuring customer-based brand equity. J. Consum. Market. 12 (4), 11-19.

Lavidge, R.J., Steiner, G.A., 1961. A model for predictive measurements of advertising effectiveness. J. Market. 25 (6), 59-62.

Lemon, K.N., Verhoef, P.C., 2016. Understanding customer experience throughout the customer journey. J. Market. 80 (6), 69-96.

Leong, V.S., Hibbert, S., Ennew, C., 2018. Communicating value to enhance service visualization. J. Serv. Market. 32 (6), 645-656.

Liu, C.-R., Liu, H.-K., Lin, W.-R., 2015. Constructing customer-based museums brand equity model: the mediating role of brand value. Int. J. Tourism Res. 17 (3), 229-238.

Liu, M.T., Wong, I.A., Tseng, T.-H., Chang, A.W.-Y., Phau, I., 2017. Applying consumerbased brand equity in luxury hotel branding. J. Bus. Res. 81, 192-202.

Liu, Y., Li, K.J., Chen, H.A., Balachander, S., 2017. The effects of products' aesthetic design on demand and marketing-mix effectiveness: the role of segment prototypicality and brand consistency. J. Market. 81 (1), 83-102.

Lovelock, C., Gummesson, E., 2004. Whither Services Marketing? In search of a new paradigm and fresh perspectives. J. Serv. Res. 7 (1), 20-41.

Lovelock, C., Wirtz, J., 2011. In: Services Marketing: People, Technology, Strategy, seventh ed. Prentice Hall, New York, USA.

MacKenzie, S.B., Podsakoff, P.M., Podsakoff, N.P., 2011. Construct measurement and validation procedures in MIS and behavioral research: integrating new and existing techniques. MIS Q. 35 (2), 293-334.

MAHB, 2019. Malaysia Airports Annual Report 2018. Retrieved January 5, 2018. https ://www.malaysiaairports.com.my/sustainability/reports.

Mehrabian, A., Russell, J.A., 1974. An Approach to Environmental Psychology. The MIT Press, Cambridge, MA, US.

Merz, M.A., He, Y., Vargo, S.L., 2009. The evolving brand logic: a service-dominant logic perspective. J. Acad. Market. Sci. 37 (3), 328-344.

Mitchell, V.W., Schlegelmilch, B.B., Mone, S.-D., 2016. Why should I attend? The value of business networking events. Ind. Market. Manag. 52, 100-108.

Mizik, N., 2014. Assessing the total financial performance impact of brand equity with limited time-series data. J. Market. Res. 51 (6), 691-706.

Na, W.B., Marshall, R., Keller, K.L., 1999. Measuring brand power: validating a model for optimizing brand equity. J. Prod. Brand Manag. 8 (3), 170-184.

Nam, J., Ekinci, Y., Whyatt, G., 2011. Brand equity, brand loyalty and consumer satisfaction. Ann. Tourism Res. 38 (3), 1009-1030.

Oliveira, M.P. V.d., Handfield, R., 2019. Analytical foundations for development of realtime supply chain capabilities. Int. J. Prod. Res. 57 (5), 1571-1589.
Olsson, L.E., Friman, M., Pareigis, J., Edvardsson, B., 2012. Measuring service experience: applying the satisfaction with travel scale in public transport. J. Retailing Consum. Serv. 19 (4), 413-418.

Österle, B., Kuhn, M.M., Henseler, J., 2019. The dynamic nature of brand experience. In: Rossi, P., Krey, N., Series (Eds.), Finding New Ways to Engage and Satisfy Global Customers (Proceedings of the 2018 Academy of Marketing Science (AMS) World Marketing Congress (WMC) Ed. Springer International Publishing, Cham, pp. 789-799.

Pappu, R., Quester, P., 2017. A commentary on "conceptualising and measuring consumer-based brand-retailer-channel equity". J. Retailing Consum. Serv., 101405

Park, S., Gupta, S., 2012. Handling endogenous regressors by joint estimation using copulas. Market. Sci. 31 (4), 567-586.

Pike, S., Bianchi, C., 2016. Destination brand equity for Australia:testing a model of CBBE in short-haul and long-haul markets. J. Hospit. Tourism Res. 40 (1), 114-134.

Pinar, M., Girard, T., Trapp, P., Eser, Z., 2016. Services branding triangle: examining the triadic service brand promises for creating a strong brand in banking industry. Int. J. Bank Market. 34 (4), 529-549.

Podsakoff, P.M., MacKenzie, S.B., Lee, J.-Y., Podsakoff, N.P., 2003. Common method biases in behavioral research: a critical review of the literature and recommended remedies. J. Appl. Psychol. 88 (5), 879-903.

Polonsky, M., Jevons, C., 2009. Global branding and strategic CSR: an overview of three types of complexity. Int. Market. Rev. 26 (3), 327-347.

Prentice, C., Correia Loureiro, S.M., 2017. An asymmetrical approach to understanding configurations of customer loyalty in the airline industry. J. Retailing Consum. Serv. 38 (September 2017), 96-107.

Ramayah, T., Cheah, J., Chuah, F., Ting, H., Memon, M.A., 2018. In: Partial Least Squares Structural Equation Modeling (PLS-SEM) Using SmartPLS 3.0: an Updated and Practical Guide to Statistical Analysis, second ed. Pearson, Singapore.

Ramsey, J.B., 1969. Tests for specification errors in classical linear least-squares regression analysis. J. Roy. Stat. Soc. B 31 (2), 350-371.

Rodrigues, P., Martins, F.V., Hayes, S., 2016. Perceptual and behavioural dimensions: measuring brand equity consumer based. J. Fash. Mark. Manag.: Int. J. 20 (4), 507-519.

Roy, S., Sreejesh, S., Bhatia, S., 2019. Service quality versus service experience: an empirical examination of the consequential effects in B2B services. Ind. Market. Manag. 82, 52-69.

Sarker, M., Mohd-Any, A.A., Kamarulzaman, Y., 2019. Conceptualising consumer-based service brand equity (CBSBE) and direct service experience in the airline sector. J. Hospit. Tourism Manag. 38 (March 2019), 39-48.

Sarstedt, M., Mooi, E., 2019. In: A Concise Guide to Market Research: the Process, Data, and Methods Using IBM SPSS Statistics, third ed. Springer, Berlin, Heidelberg.

Sarstedt, M., Ringle, C.M., Cheah, J.-H., Ting, H., Moisescu, O.I., Radomir, L., 2019. Structural model robustness checks in PLS-SEM. Tourism Economics, January 2019, $1-24$.

Schallehn, M., Burmann, C., Riley, N., 2014. Brand authenticity: model development and empirical testing. J. Prod. Brand Manag. 23 (3), 192-199.

Šrić, M., Gil-Saura, I., Mikulić, J., 2017. Customer-based brand equity building Empirical evidence from Croatian upscale hotels. J. Vacat. Mark. 23 (2), 133-144.

Shmueli, G., Sarstedt, M., Hair Joseph, F., Cheah, J.-H., Ting, H., Vaithilingam, S., Ringle Christian, M., 2019. Predictive model assessment in PLS-SEM: guidelines for using PLSpredict. Eur. J. Market. 53 (11), 2322-2347.

Shostack, G.L., 1982. How to design a service. Eur. J. Market. 16 (1), 49-63.

SKYTRAX, 2019. The world's top 100 airlines in 2018. Retrieved April 4 2019. https ://www.worldairlineawards.com/worlds-top-100-airlines-2018/.

Smahel, T., 2017. Airport features most likely to affect international traveler satisfaction. Transport. Res. Rec.: Journal of the Transportation Research Board 2626 (1), 34-41.

So, K.K.F., King, C., 2010. "When experience matters": building and measuring hotel brand equity: the customers' perspective. Int. J. Contemp. Hospit. Manag. 22 (5), 589-608.

Statista, 2020. Number of scheduled passengers boarded by the global airline industry from 2004 to 2020 (in millions). Retrieved January 13, 2020. https://www.statista. $\mathrm{com} /$ statistics/564717/airline-industry-passenger-traffic-globally/.

Svensson, G., Ferro, C., Høgevold, N., Padin, C., Carlos Sosa Varela, J., Sarstedt, M., 2018. Framing the triple bottom line approach: direct and mediation effects between economic, social and environmental elements. J. Clean. Prod. 197, 972-991.

Sweeney, J.C., Soutar, G.N., 2001. Consumer perceived value: the development of a multiple item scale. J. Retailing 77 (2), 203-220.

Taheri, B., Olya, H., Ali, F., Gannon, M.J., 2019. Understanding the influence of airport servicescape on traveler dissatisfaction and misbehavior. J. Trav. Res. (October 2019), 1-21.

Thakshak, 2018. Analysing customer based airline brand equity: perspective from Taiwan. Future Business Journal 4 (2), 233-245.

Thuy, N.P., 2011. Using service convenience to reduce perceived cost. Market. Intell. Plann. 29 (5), 473-487.

Tourism Malaysia, 2019. Malaysia tourism statistics in brief: facts and figure overview 2018. Retrieved January 14, 2020. https://www.tourism.gov.my/statistics.

U1 Islam, J., Rahman, Z., 2017. The impact of online brand community characteristics on customer engagement: an application of Stimulus-Organism-Response paradigm. Telematics Inf. 34 (4), 96-109.

van Osselaer, S.M.J., Janiszewski, C., 2001. Two ways of learning brand associations. J. Consum. Res. 28 (2), 202-223.

Vargo, S.L., Lusch, R.F., 2004. Evolving to a new dominant logic for marketing. J. Market. 68 (1), 1-17.

Vargo, S.L., Lusch, R.F., 2016. Institutions and axioms: an extension and update of service-dominant logic. J. Acad. Market. Sci. 44 (1), 5-23. 
Vargo, S.L., Lusch, R.F., 2017. Service-dominant logic 2025. Int. J. Res. Market. 34 (1), 46-67.

Verhoef, P.C., Lemon, K.N., Parasuraman, A., Roggeveen, A., Tsiros, M., Schlesinger, L. A., 2009. Customer experience creation: determinants, dynamics and management strategies. J. Retailing 85 (1), 31-41.

Walsh, G., Mitchell, V.W., 2010. Consumers' intention to buy private label brands revisited. J. Gen. Manag. 35 (3), 3-24.

Wang, Y.-C., Hsu, K.-C., Hsu, S.-H., Hsieh, P.-A.J.J., 2011. Constructing an index for brand equity: a hospital example. Serv. Ind. J. 31 (2), 311-322.

World Economic Forum, 2020. The travel \& tourism competitiveness report 2019: travel and tourism at a tipping point. Retrieved January 24, 2020. https://www.weforum. org/reports/the-travel-tourism-competitiveness-report-2019.

Yoo, B., Donthu, N., Lee, S., 2000. An examination of selected marketing mix elements and brand equity. J. Acad. Market. Sci. 28 (2), 195-211.

Zeithaml, V.A., 1981. How consumer evaluation processes differ between goods and services. In: Donnelly, J.H., George, W.R. (Eds.), Marketing of Services. American Marketing Association, Chicago, pp. 186-190.

Zeithaml, V.A., 1988. Consumer perceptions of price, quality, and value: a means-end model and synthesis of evidence. J. Market. 52 (3), 2-22.

Moniruzzaman Sarker is a Lecturer at the Department of Marketing, Sunway University Business School, Sunway University, Malaysia. He received his PhD in Marketing from the Faculty of Business and Accountancy, University of Malaya (UM), Malaysia. His research interest revolves around services branding, customer experience and behavior, service quality, transportation services, and travel and tourism services. His research works have appeared in the Journal of Hospitality and Tourism Management, Tourism Management Perspectives, among others. Email: mrajib.sarker@gmail.com; msarker@sunway.edu.my

Amrul Asraf Mohd-Any is a Senior Lecturer at the Department of Marketing, Faculty of Business and Accountancy, University of Malaya (UM), Malaysia. He received his PhD in Business \& Management (Marketing) from the University of Nottingham, UK. He also holds an MSc in International Hospitality Management from the University of Strathclyde in Glasgow, UK. His research lies in the area of services marketing and internet marketing, with specific focus and interest in value co-creation, customer participation and online customer engagement. His works have appeared in the Journal of Travel Research, Electronic Markets, Journal of Service Theory and Practice, Journal of Hospitality and Tourism Management, among others; as well as two chapters in a services marketing case study book. Email: amrul_asraf@um.edu.my

Yusniza Kamarulzaman is an Associate Professor and the Director of Graduate School of Business at the Faculty of Business and Accountancy, University of Malaya (UM), Malaysia. She received her PhD in Marketing from Cardiff University, UK, and Postgraduate Diploma in Entrepreneurship from Cambridge University, UK. She is actively involved in marketing research, consultation, and corporate training in Malaysia. She is also on the external advisory boards of a number of Malaysian public and private universities. Her publications include articles, books and book chapters, monographs, and course modules. Her two other popular books are Principles of Marketing and Marketing Management. Email: yusniza@um.edu.my 